\title{
CSR and Financial Performance: Trick or Treat? A Longitudinal Study on Holistic CSR Practices
}

\author{
Antonio Salvi $^{1}$, Felice Petruzzella ${ }^{1} \&$ Anastasia Giakoumelou ${ }^{1}$ \\ ${ }^{1}$ Department of Economics and Management, University LUM Jean Monnet, Italy \\ Correspondence: Felice Petruzzella, Department of Economics and Management, University LUM Jean Monnet, \\ Italy. E-mail: petruzzella@lum.it
}

Received: March 25, 2018

Accepted: April 30, 2018

Online Published: May 15, 2018

doi:10.5539/ijbm.v13n6p43

URL: https://doi.org/10.5539/ijbm.v13n6p43

\begin{abstract}
This paper aims to test the impact that a firm's adopted CSR level has on its financial performance, in terms of accounting, financial and market-based measures. In particular, we employ a panel OLS analysis to test the effect of firm's sustainable efforts (measured by the "Sustainable score", a tailor-made variable) on three performance measures: return on assets (ROA), return on equity (ROE) and Tobin's Q.

This work provides for methodological differences that led to divergent research results over existing literature in the field, examining the relationship of interest within three timeframes that exploit underlying dynamics over both long- and short-term horizons. Furthermore, we contributed to current knowledge focusing on the effect of holistic CSR practices on financial performance and examining the impact of the 2007 financial crisis on the relationship. To that end, we have employed a customized measure to represent effective CSR practices that go beyond CSR-washing cases and studies of CSR through single-dimension variables, while quantitatively exploring the relationship of interest within three separate time periods that span both before and after the financial meltdown of 2007.

Results highlight a positive relationship between the operating and financial performance of companies and their sustainability commitment. What is more, findings indicate that CSR individual actions do not produce any significant impact on firms' performance, unless applied jointly through a holistic sustainability strategy. Finally, the relationship between the sustainability level of a firm and its financial performance presents various significance levels and temporal profiles, with the years to follow the financial downturn of 2007 presenting the strongest results as opposed to the absence of important influence during the pre-crisis period.
\end{abstract}

Keywords: CSR, financial performance, holistic CSR, sustainable score, stakeholder theory

\section{Introduction}

Sustainability has become a mantra for the $21^{\text {st }}$ century (Dyllick \& Hockerts, 2002; Mirvis \& Googins, 2006; Wood, 2010). Social, ecological and economic challenges gain additional significance and global dimensions because of their impact and the interest they raise among societies, consumers, managers and politicians. A commonly shared idea is that a transition to more environmentally and socially responsible conducts would allow preserving the earth's ecosystem and drive economic growth is necessary; an idea that has grown even stronger during the recession and its aftermath (Ellis \& Bastin, 2011; Margolis \& Walsh, 2003; Mills, 2014), a fact explored and confirmed by the findings of this study.

In an era that views firms as a disconnected part of societies and a source of externalities, the corporate world is met with the challenge to falsify skepticism around the contribution of companies to their environment and society that goes beyond their profit-related objectives. In this direction, more recent events and corporate behaviors, come to also point the finger to more in-depth responsibility and the adoption of an effective sustainable strategy that goes further than mere symbolic or purposely void CSR-washing actions (Alves, 2009; Jahdi \& Acikdilli, 2009; Pope \& Wæraas, 2016; Walker \& Wan, 2012). Among management scholars, CSR capabilities are one of the most debated issues during past decades. Various academics have investigated how managers choose among various CSR strategies able to improve a firm's financial performance (Dowell et al., 2000; King \& Lenox, 2001, 2002; Rangan et al., 2015; Wood, 2010) but little is known regarding holistic sustainability approaches from an empirical standpoint (Lozano, 2013). Another branch of researchers, instead, has explored when managers select to have their firms participate in various forms of self-regulation in order to improve green management practices 
(Berchicci \& King, 2007).

We will start with a review of current literature addressing the effect of sustainable practices on firm performances and the development of our hypotheses. Proceeding this, we will elaborate on the data selection and sample construction processes, while the applied methodology is explained in a separate section. Then, we will outline the findings of the present study and to conclude, we will comment and discuss the study's outcomes along with their major implications, providing insights for future developments in this field of interest.

\section{Literature Review}

The relationship between corporate social responsibility (CSR) and corporate financial performance (CFP) has troubled academics and researchers worldwide with contradicting results (Perrini et al., 2011), evolving in one of the most debated areas in managerial and financial studies (Barnett, 2007).

For many years, scholars have assumed that investments to protect the earth's ecosystem and improve the firm's connection with the community it operates in, provide little to no financial benefits. In this direction, CSR has been defined as the course of action that companies undertake in order to promote social good, exceeding the sole objectives set by shareholders and mere legal constraints (McWilliams \& Siegel, 2001). Gradually, however, due to the growing importance of the concept of CSR, the linkage between society and firms has become a pillar of modern corporate strategy and thinking. Pioneer researchers early agreed that investments in this field can provide benefits for both the environment and firms (Bragdon \& Marlin, 1972; Boulding, 1956; Nelson, 1994; Porter \& van der Linde, 1995). Nevertheless, the existence, direction and mechanisms underlying this relationship (Endrikat, 2015; Horváthová, 2010; Margolis et al., 2007; Perrini et al., 2011; Russo \& Fouts, 1997), with a particular focus on the reverse causality effect (Hart \& Ahuja, 1996; King \& Lenox, 2001, 2002), are still put to the test by a series of scholars worldwide. It is worth pointing out that a heated debate has been raised as to whether it is that more profitable companies simply have a higher level of resources to engage in CSR efforts (slack resource theory) or it is the actual CSR practices that lead to improved profitability (good management theory) (Waddock \& Graves, 1997). Therefore, despite the fact that an extended amount of academic works find support for a strong relationship between CSR and firm financial performance, it still remains to be verified whether it is indeed CSR improvements that drive higher financial benefits or the other way around. Following Perrini et al. (2011), CSP can be defined as "the outcome of implementing CSR activities and behaviors, thus comprising principles of social responsibility, processes of social responsiveness, and policies, programs, and observable outcomes as they relate to the firms' relationships with stakeholders".

The concept of corporate social performance seems to be rooted in 1950s and derives from the Boulding's idea (1956) that "view of complex organizations as open systems, intricately connected to their larger environments" (Wood, 2010). Few years later and starting from the Bragdon \& Marlin's research (1972), one of the earliest study concerning the relationship between CSP and CFP, revealed a positive link, more than forty years have been spent investigating this relationship with different approaches and findings (Arlow \& Gannon, 1982; Margolis et al., 2007; Orlizky et al., 2003).

In 1995, Porter \& van der Linde proposed, in an innovative article titled "Toward a New Conception of the Environment-Competitiveness Relationship", that "by stimulating innovation, strict environmental regulations can actually enhance competitiveness" and thus "partially or more than fully offset the costs of compliance" (the Porter hypothesis). This claim stimulated organized research on the link between CSR and financial goals (Berchicci \& King, 2007) and urged firms to enlarge their range of constituencies in order to share value not only with their shareholders but also with a wide series of stakeholders. According to a U.S. research, people are willing to pay more for products that save the environment (Rosewicz, 1990), while more up-to-date research papers argue that several factors moderate the relationship between a firm's sustainable efforts and consumers' empathy (Lii et al., 2013; Russell et al., 2016), a concept that we follow in this study with regards to the stance markets take on the actual sustainability levels adopted, instead of efforts. In fact, many international firms now publish separate annual social and environmental performance reports or enhance media coverage on such matters (Chan \& Walter, 2014; Klassen \& McLaughlin, 1996) as a response to the latter and a series of academic works suggest that corporate social disclosure leads to improved performance when it comes to stock prices or accounting standards (Burhan \& Rahmanti, 2009; Khanna \& Damon, 1999; Santoso \& Feliana, 2014). These data are provided by firms in a clear and verifiable manner, similar to economic and financial data, in order to provide a comprehensive picture concerning their sustainable efforts (KPMG, 2008). Further academic research has also highlighted the benefits of voluntary and consistent disclosure (Allegrini \& Greco, 2011; Cinquini et al., 2012) of non-financial information related to intellectual capital, with a peak focus on human capital, that can derive from increased transparency regarding operations, as well as improved relationships with various stakeholder groups (Passetti et 
al., 2009; Robb et al., 2001). Strong CSR management is viewed either as a competitive asset or a liability for firms that still often present irresponsible actions and behavior (Mirvis \& Googins, 2006; Wu, 2014).

Interestingly enough, there is a lack of consensus around this aspect, despite the fact that the majority of researchers posit that a relationship between CSR and economic performance exists and it is positive and statistically relevant (Kim et al., 2014). Under stakeholder theory (Freeman, 1984) and resource-based view perspective (Barney, 1991; Bansal, 2005), sustainability-related events can be considered to provide strong signalling potential with respect to the firm's capability to gain competitive advantages and meet expectations of various stakeholders. The underlying concept puts stakeholders out of their perception as mere factors of production within the neoclassical view of the firm (Misani, 2017). As a matter of fact, stakeholder satisfaction becomes a crucial driver of organizational outcomes.

Even with respect to the mere definition of corporate social responsibility there seems to be no wide ground of consensus regarding practices and conducts involved. According to Aguinis \& Glavas (2012), "the definition of CSR refers to policies and actions by organizations, such policies and actions are influenced and implemented by actors at all levels of analysis (e.g., institutional, organizational, and individual)". Corporate sustainability (CS) can also be defined as "meeting the needs of a firm's direct and indirect stakeholders (such as shareholders, employees, clients, pressure groups, and communities), without compromising its ability to meet the needs of future stakeholders as well" (Brundtland, 1987).

In this study, we adopt a view that places environmental management as an important, but not unique, corporate task within CSR strategies. As a matter of fact, CSR management is one significant component of functional strategy. Given that, strategy is defined as the pattern of structural and infrastructural choices that guide firm decisions and support objectives; CSR management affects both structural and infrastructural components and, as a consequence, the underlying management system; it is able to provide market gains and cost savings at the same time (Klassen \& McLaughlin, 1996). Due to the aforementioned reasons, understanding and measuring the magnitude of the link between CSR and financial performance proves to be crucial nowadays.

At this point it is crucial to also point out how, over the past decades, researchers have applied different statistical and econometrical models to test the hypothesis that a relationship between a firm's financial performance and degree of sustainability exists. Notwithstanding this fact, there is an intense debate among managers, practitioners and academics around the "does it pay to be green?" question (King \& Lenox, 2001), along with a strong disagreement on the validity of the various measures put in place to operationalize the underlying concepts (Endrikat, 2015; Golicic \& Smith, 2013; Gregory \& Whittaker, 2012; Horváthová, 2010). Most recent literature has employed several operating, financial and sustainability measures to represent performance: (1) Tobin's Q, ROA, ROI, ROIC or ROE as operating or financial performance measures or (2) capital expenditure on pollution control, emission of toxic chemicals, spills accidents, the percentage of emission reduction or the degree or resources reduction as CSR performance measures (Christmann, 2000; Hart \& Ahuja, 1996; Khanna \& Damon, 1999; King \& Lenox, 2001, 2002; Konar \& Cohen, 2001; Lech, 2013; Link \& Naveh, 2006; Russo \& Fouts, 1999; Wagner, 2005;). This study attempts to fill the void in previous works by adopting a novel approach, under which CSR practices are measured in a manner that reflects the totality of actions taken by the firm and do not focus on single-variable views of CSR commitment neither on a single aspect of sustainability.

Despite recent research focus on the relationship between CSP and CFP, CSR literature remains highly fragmented (Aguinis \& Glavas, 2012), while, as pointed out by Waddock (2004), "parallel and sometimes confusing universes exist". According to Aguinis \& Glavas (2012) and their comprehensive literature review on 588 journal articles and 102 books and book chapters, the reasons of this fragmentation might derive essentially from: (1) the different disciplinary and conceptual lenses adopted by scholars studying this phenomenon and (2) the level of analysis considered running the study (macro or micro level).

Literature often highlights a positive and statistically relevant connection between CSR and financial measures of firm's performance (Christmann, 2000; Dowell et al., 2000; Dumitrescu \& Simionescu, 2013; Golicic \& Smith, 2013; Hart \& Ahuja, 1996; King \& Lenox, 2001; Klassen \& McLaughlin, 1996; Russo \& Fouts, 1997). The majority of researchers agree that superior CSR performance is linked to better financial performance (Margolis \& Walsh, 2003) and report a causal relationship in both directions (Berchicci \& King, 2007). In contrast with the studies that support a liaison between sustainability and corporate financial goals, a series of authors indicate the existence of a null or negative relation between strong CSR practices and a firm's financial results (Friedman, 1970; González-Benito \& González-Benito, 2005; Jensen, 2001; Khanna \& Damon, 1999; Lech, 2013; Link \& Naveh, 2006; Wagner, 2005). Furthermore, a series of studies indicate that any bond between corporate social and financial performance is too weak to provide helpful insights (Nelling \& Webb, 2008) or that such relationship 
only exists in a short-lived time frame which cannot be considered valuable (Nakamura, 2011). Mixed results have been widespread through literature in the realm of CSR and financial performance and still generate intense debate (Garcia-Castro et al., 2010; Griffin \& Mahon, 1997; Margolis \& Walsh, 2001, 2003; Post et al., 2002; Roman et al., 1999; Ullmann, 1985). In fact, Margolis \& Walsh (2003) provided one of the most comprehensive reviews in the field (127 studies regarding the relationship between social practices and firm's performance have been examined) concluding that in 109 cases social practices are used to predict a firm's financial performance with 54 cases suggesting a positive relationship, 20 cases suggesting a mix of positive and negative results and 28 cases where such relationship appears of no significance.

Table 1 summarizes the most relevant literature in the field, showing the different measures used to operationalize corporate sustainable efforts and financial goals, highlighting differences among obtained findings (classified in terms of results: positive, null and negative relationship).

Table 1. The relationship between CSP and CFP

\begin{tabular}{|c|c|c|c|}
\hline Author(s) & CSR measure & CSP measure & Relationship \\
\hline Bragdon \& Marlin (1972) & Indices of pollution records & Earnings, ROE, ROC & Positive relationship \\
\hline Heart \& Ahuja (1996) & $\begin{array}{l}\text { Efforts to prevent pollution and } \\
\text { reduce emissions }\end{array}$ & ROS, ROA and ROE & Positive relationship \\
\hline $\begin{array}{l}\text { Klassen \& McLaughlin } \\
\text { (1996) }\end{array}$ & $\begin{array}{l}\text { Environmental management } \\
\text { practices }\end{array}$ & Market-based measure & Positive market reaction \\
\hline Waddock \& Graves (1997) & $\begin{array}{l}\text { Customized sustainable index based on } \\
\text { KLD ratings }\end{array}$ & ROA, ROE and ROS & Positive relationship \\
\hline $\begin{array}{l}\text { Russo \& Fotus } \\
\text { (1999) }\end{array}$ & Environmental ratings & ROA & Positive relationship \\
\hline Christmann (2000) & $\begin{array}{l}\text { Best practices of environmental } \\
\text { management }\end{array}$ & Cost reduction & Positive relationship \\
\hline Dowell et al. (2000) & Corporate environmental standard & Stock market performance & Positive impact \\
\hline $\begin{array}{l}\text { King \& Lenox } \\
(2001)\end{array}$ & Total, relative and industry emissions & Tobin's Q & $\begin{array}{l}\text { Positive relationship influenced } \\
\text { by firm's fixed } \\
\text { characteristics }\end{array}$ \\
\hline Konar \& Cohen (2001) & $\begin{array}{l}\text { Aggregate pounds of toxic chemicals } \\
\text { emitted }\end{array}$ & Tobin's Q & $\begin{array}{l}\text { Positive impact of pollution } \\
\text { reduction on firm's value }\end{array}$ \\
\hline Burhan \& Rahmanti (2003) & Sustainability reporting & ROA & Positive relationship \\
\hline $\begin{array}{l}\text { Dumitrescu \& Simionescu } \\
(2003)\end{array}$ & $\begin{array}{l}\text { Corporate Social Responsibility reported } \\
\text { activities for employees }\end{array}$ & ROA and ROE & Positive relationship \\
\hline Hassel et al. (2005) & Index of environmental performance & Stock market performance & Positive impact \\
\hline Godfrey et al. (2009) & $\begin{array}{l}\text { CSR score provided by Socrates } \\
\text { database }\end{array}$ & $\begin{array}{l}\text { Share price (using the Event } \\
\text { study method) }\end{array}$ & Positive impact \\
\hline Nurayaman (2013) & CSR disclosure (GRI) & $\begin{array}{l}\text { ROA, net profit margin and } \\
\text { stock price }\end{array}$ & Positive impact \\
\hline Kim (2014) & MSCI ESG sustainable rating & $\begin{array}{l}\text { Crash risk measures reflect } \\
\text { firm-specific factors }\end{array}$ & Positive relationship \\
\hline Santoso \& Feliana (2014) & Corporate Social Disclosure Index (GRI) & ROA, ROE, ROS and EPS & Positive relationship \\
\hline $\begin{array}{l}\text { González-Benito \& } \\
\text { González-Benito (2005) }\end{array}$ & $\begin{array}{l}\text { Environmental proactivity measured } \\
\text { using a questionnaire }\end{array}$ & $\begin{array}{l}\text { Cost, quality, flexibility, } \\
\text { reliability and speed }\end{array}$ & Controversial results \\
\hline Wagner (2005) & $\begin{array}{l}\text { Emission of toxic chemicals and total } \\
\text { energy and water input per output }\end{array}$ & ROCE, ROE and ROS & $\begin{array}{l}\text { Controversial results; U-shaped } \\
\text { relationship }\end{array}$ \\
\hline Nakamura (2011) & Environmental investments & ROA & $\begin{array}{l}\text { Null relationship in the } \\
\text { short-term }\end{array}$ \\
\hline Lech (2013) & $\begin{array}{l}\text { Companies reporting on a specific } \\
\text { sustainability index }\end{array}$ & ROA and ROE & Null relationship \\
\hline $\begin{array}{l}\text { Khanna \& Damon } \\
\text { (1999) }\end{array}$ & $\begin{array}{l}\text { Participation at the voluntary } 33 / 50 \text { US } \\
\text { Program }\end{array}$ & ROI & Negative impact on current ROI \\
\hline $\begin{array}{l}\text { Link \& Naveh } \\
(2006)\end{array}$ & ISO 14001 standard & $\begin{array}{l}\text { Gross profit margin, } \\
\text { market share, sales and } \\
\text { sales per employee }\end{array}$ & Negative relationship \\
\hline $\begin{array}{l}\text { Nelling \& Webb } \\
(2008)\end{array}$ & $\begin{array}{l}\text { CSR rating provided by KLD database, } \\
\text { weighted by the authors }\end{array}$ & $\begin{array}{l}\text { ROA and market-based } \\
\text { measure }\end{array}$ & Controversial results \\
\hline
\end{tabular}

Source: authors' elaboration.

As depicted in Table 1, ROA, ROE and Tobin's Q are the most frequently used proxies of firm financial performance employed by researchers to measure the impact of sustainable practices on financial results; proxies 
for sustainability, instead, vary to a greater degree, causing a misalignment among research findings (Endrikat, 2015).

Academics more recently propose a new type of nexus between CSR and financial performance that partially contradicts the linear positive relationship previously studied and suggests a disaggregated U-shaped connection between the two (Barnett \& Salomon, 2012; Nollet et al., 2015). According to this movement in CSR studies, engaging and investing in sustainable efforts only pays off after a certain threshold of CSR level present in a firm has been reached, while the impact of CSR after the aforementioned critical point indicates a long-term positive pattern, results that are in line with the findings of the present study that delves into the impact of sustainability levels in the short-term as well as their duration in a long-term horizon. Concluding, a significant wave of researchers have looked into the substantial elements of the relationship, going further than the mere "causality" case and investigating the moderators of the observed connection. Cutting-edge studies propose a series of factors that drive the relationship between sustainability and performance that span from the industry of origin, region, firm size, operationalization of the sustainable practices, country and institutional context to reputation, media coverage and corporate governance adopted by the firm (Chang, 2016; Golicic \& Smith, 2013; Hoepner et al., 2010; Ortas et al., 2015; Tang et al., 2012; Wang \& Berens, 2014; Wang et al., 2015; Zygadlo et al., 2016).

This study aims to explore the relationship between firm's sustainable practices and its financial performance employing a holistic sustainability score created by the authors and labelled "Sustainable score" (SS). In a previous work, Waddock \& Graves (1997) constructed a customized sustainability index (CSP index) aiming to obtain a more robust measure of social performance based on Kinder, Lydenberg \& Domini (KLD) ratings. In this study we do not create a new sustainability index but, following Waddock \& Graves' intuition (1977), we try to build a robust sustainability score. The shared underlying idea among supporters of the CSR holistic approach, is that a firm's social efforts "should be understood as corporate activities that proactively seek to contribute to sustainability equilibria, including the economic, environmental, and social dimensions of today, as well as their inter-relations within and throughout the time dimension (i.e. the short-, long-, and longer-term), while addressing the company's systems, management and strategy, organisational systems, procurement and marketing, and assessment and communication; as well as with its stakeholders" (Lozano, 2013). Furthermore, Godfrey et al. (2009), applied a sustainability score deriving from 41 separate binary item measures of firm engagement along six social dimensions.

In light of this, our "SS" variable is not a new measure of firm sustainability, but a score attributed to each firm that helps splitting the study's sample into two subsamples which respectively include sustainable and less sustainable firms, based on their "Sustainable score" value. The dependent, independent and control variables are analysed in detail in the methodology section. All relevant variables have been chosen following the most relevant literature in the field. We run three different regression models, using the multiple Ordinary Least Square (OLS) analysis in order to test the following hypotheses within three separate timeframes that span from 2002 to 2013, from 2002 to 2006 and from 2009 to 2013 respectively. We choose to study the specific three separate periods in or d e $r$ to gain perspective on the longitudinal nature of the relationship between CSR and CFP but also to decode the net impact that the 2007 crisis had on the way CSR is viewed and employed, for which we opt to sacrifice years 2007 and 2008 of observations. Additionally, we explore the robustness of the independent variable (Sustainable score) and the validity of a holistic sustainability commitment as compared to symbolic or single-dimension CSR efforts. The research hypotheses are:

Hypothesis 1: Stronger sustainable behavior (Sustainable score) enhances the firm's operating performance (ROA), all else equal;

Hypothesis 2: Stronger sustainable behavior (Sustainable score) enhances the firm's financial market performance (Tobin's Q), all else equal;

Hypothesis 3: Stronger sustainable behavior (Sustainable score) enhances the firm's financial performance (ROE), all else equal.

\section{Data Collection}

The sample frame for this study was drawn from the S\&P Global 1200 index (Note 1). Data regarding CSR commitment and financial performance of firms were originated from Thomson Reuters Datastream Asset4 database. The ESG Asset4 Thomson Reuters Datastream data are reliable proxies of environmental, social and governance data and several studies in the literature proved their robustness (Semenova \& Hassel, 2014).

The original sample has initially been downsized to account for companies that lacked relevant data. After adjusting the sample for this first criterion and in order to obtain a balanced panel dataset, a total of 689 firms' data 
were available. The sample has been further filtered down, in order to remove outliers. At this point, our sample was comprised of 621 firms. Moving forward, we opt for the elimination of firms belonging to the financials and telecommunications industries, given the lack of proportion with respect to their environmental efforts compared to the rest of the sample. Given all previous considerations, the final sample includes 591 firms and 7,092 observations. As mentioned previously, the study is conducted upon the initial sample that covers the period 2002-2013 and two subsamples that span from 2002 to 2006 and from 2009 to 2013 respectively. Our objective here is to isolate the net effects generated by the 2007 financial turning point and delve into the relationship between CSR and financial performance before and after such shock under a mid-term prism that finds thin coverage in current literature (Giannarakis \& Theotokas, 2011). In detail, both the pre-crisis and post-crisis subsamples include 591 firms and 2,955 observations. We are confident that the sample and subsamples employed are big enough to be considered free from a non-normal distribution bias, according to the central limit theorem and the law of large numbers, according to which the distribution of the sum (or average) of a large number of independent, identically distributed (i.i.d.) variables will be approximately normal, regardless of the underlying distribution (Stock \& Watson, 2005).

Tables 2 and 3 summarize the main descriptive characteristics of this study's samples, in terms of geographical area and industry sector. The North American sample includes Canada, U.S.A. and Bermuda, while the European sample includes Austria, Belgium, Denmark, Finland, France, Germany, Ireland, Italy, Luxembourg, Netherlands, Norway, Spain, Sweden, Switzerland, and U.K. The Asian sample is comprised of China, Hong-King, Japan, Republic of Korea, Singapore and Taiwan. Finally, South America includes Brazil, Chile and Mexico and the sample for Australia only includes Australia.

Table 2. Sample composition by geographical area

\begin{tabular}{lll}
\hline GEOGRAPHICAL AREA & NUMBERS OF FIRMS & PERCENTAGE OF SAMPLE \\
\hline North America & 293 & $50 \%$ \\
Europe & 166 & $28 \%$ \\
Asia & 113 & $18 \%$ \\
Australia & 14 & $3 \%$ \\
South America & 5 & $1 \%$ \\
\hline TOTAL & $\mathbf{5 9 1}$ & $\mathbf{1 0 0 \%}$ \\
\hline
\end{tabular}

Source: authors' elaboration.

Table 3. Sample composition by industry

\begin{tabular}{lll}
\hline INDUSTRY & NUMBERS OF FIRMS & PERCENTAGE OF SAMPLE \\
\hline Industrial & 135 & $23 \%$ \\
Consumer Goods & 103 & $17 \%$ \\
Consumer Services & 84 & $14 \%$ \\
Basic Materials & 64 & $11 \%$ \\
Technology & 57 & $10 \%$ \\
Healthcare & 56 & $9 \%$ \\
Oil \& Gas & 55 & $9 \%$ \\
Utilities & 37 & $7 \%$ \\
\hline TOTAL & $\mathbf{5 9 1}$ & $\mathbf{1 0 0 \%}$ \\
\hline
\end{tabular}

Source: authors' elaboration.

\section{Methodology}

The aim of this paper is to measure the impact of a firm's CSR commitment, measured by a "Sustainable score", on its financial performance. We apply the multiple Ordinary Least Square regression (OLS) in order to test the hypotheses in the empirical part of the study. This paper tests the impact of the CSR level adopted by a firm on three different measures of economic performance that vary from market-based measures to accounting ones. We try to decode if it really pays to be green when it comes to the firm's operating and financial performance (ROA and ROE respectively), as well as its market performance (Tobin's Q). The aforementioned variables are selected among the most widely applied in relevant literature (González-Benito \& González-Benito, 2005; Hart \& Ahuja, 
1996; Heras-Saizarbitoria et al., 2011; King \& Lenox, 2001, 2002; Santoso \& Feliana, 2014) to depict different aspects of performance examined here.

\subsection{Dependent Variables}

The set of dependent variables used in the analysis is the following:

i. ROA: as a variable, ROA represents the return on assets. It is a measure of a firm's profitability calculated as the division of net income by total assets (Note 2). ROA provides a good indication of a firm's actual capacity to generate returns through the utilization of its entire productive assets base (such as equipment, goodwill, intangible assets) without considering the firm's financial structure (as ROE does). ROA is chosen as a measure of operating performance in this study (Pätäri et al., 2011).

ii. Tobin's Q: as a variable, Tobin's $Q$ is selected to represent the firm's market performance. It is measured as the market value (Note 3) of a firm relative to the replacement costs of its tangible assets (Lindenberg, 1981). This variable is used to measure a firm's marketability.

iii. ROE: as a variable, ROE represents the return on equity. It is a traditional measure of profitability calculated as the firm's net income (Note 4) divided by its shareholder's equity (Note 5) ROE, in this case, is chosen in order to measure the financial performance of firms examined.

\subsection{Independent Variables}

A wide stream of research has measured environmental performance as the degree to which firms cause toxic pollution (Hart \& Ahuja, 1996; Khanna \& Damon, 1999) or as the emissions or resources reduction (as a percentage) during the time period considered (Christmann, 2000; Kim et al., 2014). Waddock \& Graves (1997) suggested that the concept of corporate social performance (CSP) is a multidimensional construct very difficult to capture and operationalize due to the great variety of inputs and outputs involved. As a consequence, too often CSP has been measured as a single-variable construct causing serious misalignment among findings. The contribution to existing literature is the examination of the widely studied relationship between sustainable performance and a firm's profitability employing a more inclusive and robust measure for CSR commitment. Past research in the field has managed to produce invaluable insights regarding the connection between CSR performance and the financial performance of firms, applying different methodologies and various measures to capture both performance metrics, as previously analysed (forced-choice survey instruments, reputational and responsibility indices, content analysis of financial and non-financial reporting, behavioral and perceptual measures or case study). However, CSR has widely been depicted in studies through variables that reflect single dimensions of CSR practices. Given the gap in current literature and the increased interest expressed by academics and practitioners, we have focused our attention on the study of the relationship between sustainability efforts and financial performance under a holistic perspective of sustainability (Lozano, 2013).

The purpose of this work is to approach CSR applied by firms in an elaborate and comprehensive manner, creating a clear definition of CSR responsiveness and avoiding the examination of symbolic CSR actions or CSR-washing attempts. To such end, we designed an independent variable, called "Sustainable score" (SS), which reflects the overall firm's sustainability performance with respect to six different CSR dimensions. It is fundamental to highlight that the "Sustainable Score" variable does not represent a new index of sustainability elaborated by the authors to measure the degree of a firm's sustainability commitment but a mere score, resulting from the aggregation of six dimensions of firms' sustainability provided by Thomson Reuters Datastream Asset 4 database; the ultimate purpose of this tailor-made measure is to split the study's sample into two groups of more and less sustainable firms in terms of total CSR efforts. As a result, findings based on this score can be compared to findings provided by literature in the field.

The "Sustainable score" variable derives from the consideration of four dummy and two continuous variables (later transformed in dummy variables). Each of the sample's firms is assigned with a score with respect to each CSR dimension examined. Values equal to 1 represent higher CSR performance, while values equal to 0 represent lower CSR performance concerning the underlying CSR dimension. All six dimensions considered for this purpose assume the same weight in the score construction. The six CSR dimensions that give birth to our independent variable are:

1) CSR Sustainability Committee: the variable reflects the existence or less of an internal CSR committee or team in the examined firm. It assumes a value of 1 if the company operates with a CSR committee or team and a value of 0 if this is not the case. 
2) CSR Sustainability Index: the variable reflects whether the underlying company reports on belonging to a specific sustainability index. It assumes a value of 1 if the company reports on belonging to a specific sustainability index and a value of 0 if the company does not report so.

3) CSR Sustainability Reporting: the variable reflects whether the underlying company publishes a separate sustainability report or a section in its annual report dedicated to sustainability. It assumes a value of 1 if a separate sustainability report is published or a section in the firm's annual report is focused on sustainability and a value of 0 if this is not the case.

4) Corporate Responsibility Awards: the variable reflects whether the firm has received any awards for its social, ethical, community, or environmental activities and performance. It assumes a value of 1 if the company has received one or more awards and a value of 0 if no such awards have been assigned to the firm in question.

5) Emissions reduction: the variable reflects the reduction of gas emissions judged harmful to the environment by the examined firm. It is a continuous variable (in percentage) that we transformed in a dummy variable which, in turn, assumes a value of 1 if the firm's emissions reduction value is bigger than the median value of the whole sample emissions reduction values and a value of 0 if such value is smaller than the sample's median.

6) Resources reduction: the variable reflects the reduction of resources utilized in the production process of the examined firm. It is a continuous variable (in percentage) that we transformed in a dummy variable which assumes a value of 1 if the firm's resources reduction value is bigger than the median value of the whole sample resources reduction values and a value of 0 if such value is smaller than the sample's median.

The concept underlying the construction of the study's "Sustainable score" is that the variables presented above should be able to mirror, in a robust and comprehensive manner, firms' efforts in terms of sustainability assuming a 360-degree perspective. More specifically, a firm's environmental management efforts are represented by the emissions and resources reduction degree (variables 5 and 6), while the other variables depict a firm's social efforts in terms of overall sustainability (variables 1,2 and 3) and external perception (variable 4). Opposite, following Godfrey et al. (2009), researchers studying the relationship between CSR and CFP have often used "coarse-grained measures of CSR (e.g. usually a single, monolithic measure of CSR or a single proxy such as disclosure or philanthropic giving)" providing varied results influenced by operationalization choices. In light of the latter, in this study, firms receive an overall score by summing their respective performance scores on each of the six CSR-related practices. As implied, the "Sustainable score" variable can take values from 0 to 6 . Based on the latter, we also proceed to separate the firms within the sample into two groups: CSR responsible firms, which are represented by "Sustainable score" values higher than or equal to 4, and less responsible firms, which present "Sustainable score" values lower than or equal to 3.

\subsection{Control Variables}

The last group of variables employed in this analysis includes a series of control variables presented in the summary of Table 4 and commonly used in literature (Hart \& Ahuja, 1996; King \& Lenox, 2001):

1) Firm Size (FS): the variable represents the firm's size and is calculated as the natural logarithm of the company's total assets. The rationale behind such choice of proxy for firm size is to avoid mechanical correlation with the aforementioned control variable, given Tobin's Q uses market capitalization as nominator (Dang \& $\mathrm{Li}, 2015$ ). Furthermore, firm size based on this formula helps us ensure comparability with lustrous studies of prominent scholars in the field.

2) Leverage (LEV): the variable represents the firm's leverage and is calculated as the company's total debt divided by its shareholder's equity. Although leverage is mainly relevant regarding the ROE dependent variable, we include it for reasons of completeness.

3) Research and Development Intensity (R\&D I): the variable represents the firm's research and development intensity and is calculated as the company's research and development expenses divided by its net sales or revenues (Note 6).

4) EBITDA Margin (E\%): the variable represents the firm's EBITDA margin, a measure of profitability, and is calculated by dividing the company's EBITDA (Note 7) by its net sales or revenues. 
Table 4. Variables summary

\begin{tabular}{|c|c|c|}
\hline VARIABLE & SYMBOL & DESCRIPTION \\
\hline \multicolumn{3}{|r|}{ DEPENDENT VARIABLES } \\
\hline Return on Assets & ROA & $\begin{array}{l}\text { The variable represents the return on assets. It is a measure of a firm's profitability calculated as } \\
\text { the division of net income by total assets. }\end{array}$ \\
\hline Tobin's Q & Tobin's Q & $\begin{array}{l}\text { The variable represents the firm's market performance. It is measured as the market value of a firm } \\
\text { relative to the replacement costs of its tangible assets. }\end{array}$ \\
\hline Return on Equity & ROE & $\begin{array}{l}\text { The variable represents the return on equity. It is a traditional measure of profitability calculated as } \\
\text { the firm's net income divided by its shareholder's equity. }\end{array}$ \\
\hline \multicolumn{3}{|r|}{ INDEPENDENT VARIABLE } \\
\hline Sustainable score & SS & $\begin{array}{l}\text { This variable is a score, elaborated by the author, derived by the aggregation of six dimensions of } \\
\text { firms' sustainability provided by Thomson Reuters Datastream Asset } 4 \text { database. } \\
\text { CONTROL VARIABLES }\end{array}$ \\
\hline Firm Size & $\mathrm{FM}$ & $\begin{array}{l}\text { The variable represents the firm's size and is calculated as the natural logarithm of the company's } \\
\text { total assets. }\end{array}$ \\
\hline Leverage & LEV & $\begin{array}{l}\text { The variable represents the firm's leverage and is calculated as the company's total debt divided } \\
\text { by its shareholder's equity. }\end{array}$ \\
\hline $\begin{array}{l}\text { Research and } \\
\text { Development Intensity }\end{array}$ & R\&D I & $\begin{array}{l}\text { The variable represents the firm's research and development intensity and is calculated as the } \\
\text { company's research and development expenses divided by its net sales or revenues. }\end{array}$ \\
\hline EBITDA margin & $\mathrm{E} \%$ & $\begin{array}{l}\text { The variable represents the firm's EBITDA margin, a measure of profitability, calculated by } \\
\text { dividing the company's EBITDA by its net sales or revenues. }\end{array}$ \\
\hline
\end{tabular}

Source: authors' elaboration.

Before proceeding with the analysis method, Table 5 provides the descriptive statistics and matrix correlation concerning the dependent, independent and control variables employed, which exclude any collinearity bias in the sample.

Table 5. Matrix correlation

\begin{tabular}{|c|c|c|c|c|c|c|c|c|c|c|}
\hline & MEAN & SD & R\&D I & FS & LEV & E\% & ROE & ROA & TQ & SS \\
\hline R\&D I & 0.04 & 0.19 & 1.00 & & & & & & & \\
\hline FS & 17.06 & 2.32 & $-0.06 * * *$ & 1.00 & & & & & & \\
\hline LEV & 0.69 & 3.05 & -0.02 & $0.05^{* * *}$ & 1.00 & & & & & \\
\hline E\% & 0.04 & 12.05 & 0.00 & 0.01 & 0.00 & 1.00 & & & & \\
\hline ROE & 15.59 & 52.61 & $-0.05 * * *$ & $-0.08 * * *$ & $0.03 * *$ & 0.01 & 1.00 & & & \\
\hline ROA & 10.86 & 12.48 & $-0.13 * * *$ & $-0.21 * * *$ & $-0.04 * * *$ & $0.03 * *$ & $0.31 * * *$ & 1.00 & & \\
\hline TQ & 1.39 & 1.57 & $0.09 * * *$ & $-0.29 * * *$ & $-0.08 * * *$ & 0.00 & 0.13 & $0.38 * * *$ & 1.00 & \\
\hline SS & 0.40 & 0.49 & -0.02 & $0.22 * * *$ & 0.00 & 0.01 & -0.01 & 0.00 & $-0.13 * * *$ & 1.00 \\
\hline
\end{tabular}

Source: authors' elaboration.

Note. $* \mathrm{p}<0.10, * * \mathrm{p}<0.05, * * * \mathrm{p}<0.01$ (two-tailed test).

\section{Analysis}

Passing to the analysis part of the work, we apply the OLS regression temporal dummies defined also as a Least Square Dummy Variable model (LSDV). To test our primary hypotheses, we run six versions of the model that show how the firm's degree of CSR commitment affects the three aspects (dependent variables) of financial performance examined. Three OLS regressions are applied on both the subsamples and the main sample to reflect the impact of CSR levels on ROA, ROE and Tobin's Q of the underlying firms. This approach is currently used in empirical studies on the value relevance of financial and non-financial information (Lourenço et al., 2012).

Elaborating the model, we conduct the Hausman test to select between fixed and random effects analysis to render the model more robust. "Because firms may differ in ways that I do not capture with our independent variables, we include dummy variables that allow each firm to have a different constant value. This is a fixed effects analysis because it reduces the possibility that a firm's fixed attributes confound the analysis" (King \& Lenox, 2001). The test results regarding the three OLS versions suggest that we may apply the fixed effects model for our sample and subsamples. In sum, to run our regressions, we use a panel multiple OLS model with 
fixed effects controlled for temporal, country and industry dummy variables. In this work, the equations used (Equations 1,2 and 3) to explain the relationship between CSR and firm's performance are summarized as follows:

$$
\begin{aligned}
& \mathrm{ROA}=\alpha+\beta_{1} \mathrm{R} \& \mathrm{D}+\beta_{2} \mathrm{FS}+\beta_{3} \mathrm{LEV}+\beta_{4} \mathrm{E} \%+\beta_{5} \mathrm{SS}+\varepsilon_{\mathrm{i}} \\
& \text { Tobin's } \mathrm{Q}=\alpha+\beta_{1} \mathrm{R} \& \mathrm{D}+\beta_{2} \mathrm{FS}+\beta_{3} \mathrm{LEV}+\beta_{4} \mathrm{E} \%+\beta_{5} \mathrm{SS}+\varepsilon_{\mathrm{i}} \\
& \mathrm{ROE}=\alpha+\beta_{1} \mathrm{R} \& \mathrm{D}+\beta_{2} \mathrm{FS}+\beta_{3} \mathrm{LEV}+\beta_{4} \mathrm{E} \%+\beta_{5} \mathrm{SS}+\varepsilon_{\mathrm{i}}
\end{aligned}
$$

\section{Holistic Approach Analysis}

As mentioned earlier in this study, among this study's main contributions is the perspective it assumes on the impact that effective, holistic sustainability efforts have on the financial performance of the firms that apply them. Trying to fill in the gaps of existing literature and to also account for CSR-washing cases in real practice, we chose to study CSR from a 360-degrees perspective. To meet such end, we constructed and employed the "Sustainable score" that takes into consideration and analyses the performance of firms upon six different key CSR dimensions. As a matter of fact, according to Lozano (2012), in order to effectively capture a firm's degree of CSR commitment, one should consider an ongoing adjustment to series of internal factors, as well as the firm's stakeholder approach (Lozano, 2012). This can be achieved only by combining firm efforts on different aspects of corporate sustainability, a blended outcome that the "Sustainable score" variable tries to capture.

At this point of the study, we aim to test the plausibility of our approach by examining the robustness of our independent variable as confronted with the six variables that compose it taken individually, just like Waddock \& Graves (1997) attempted to do in their study employing a customized sustainability index. In other words, we make an attempt to explore whether, indeed, a holistic CSR commitment on behalf of firms brings major benefits when compared to the application of single CSR practices that cannot make up for a holistic CSR perception of the firm or at times are considered as symbolic or CSR-washing activities. We form additional hypotheses to perform such analysis based on the six variables that represent the single CSR dimensions making up for the independent variable (see Appendix E for detailed hypotheses).

\section{Results}

The key findings of this study are presented and analysed in this section. Results are robust to the effect of multicollinearity, outliers and non-linearity. We run a Variance Inflation Factor test (VIF) to make sure that multicollinearity does not affect the panel and the obtained VIF values (see Appendix A) in our regression models are considerably within the limit, as none of them approached the critical value of 10 (Stock \& Watson, 2005). Finally, the results of the models that test our hypotheses are demonstrated in Tables 6, 7 and 8.

Proceeding with the actual results, Table 6 presents all findings regarding the main sample that covers the long-term relationship between CSR and financial performance all through 2002 to 2013 . We find support for a positive relationship between the firm's total CSR commitment, measured by the "Sustainable Score", its operating performance measured by ROA, and its marketability measured by Tobin's Q, which is verified at a $10 \%$ significance level, supporting Hypothesis 1 and 2. Hypothesis 3, on the other hand, is not supported by findings that suggest a positive but not significant relationship between the firm's sustainable conduct and its financial performance measured by ROE. In the meantime, firm size and R\&D intensity, among the control variables, appear strongly connected to a superior performance. Such finding can easily be attributed to the major attention that firms with a propensity to invest in innovation and internal improvement can pay to their sustainability profiles, as well as the increased funds for investment in CSR efforts available to bigger firms, in terms of assets. Results also appear consistent with current literature in the field (Dowell et al., 2000; Hart \& Ahuja, 1996; Kim et al., 2014; King \& Lenox, 2001) that provide insight for a positive and significant relationship between the operating and market performance of companies and the level of CSR standards they employ. Results are also coherent with Waddock \& Graves' study (1997) of CSR and financial performance based on a customized sustainability index.

The analysis performed on the mid-term relationship between CSR commitment and financial performance and focused on the pre-crisis subsample surprisingly does not confirm our previous findings (Table 7). None of the hypotheses covering the three measures of performance and the firm's CSR commitment level appears to be supported in this case. Opposite to such findings, we find support for all three hypotheses when exploring the relationship of interest within the post-crisis subsample that spans from 2009 to 2013. Our findings concerning the second subsample are presented in Table 8 and indicate a positive and significant at a $10 \%$ significance level relationship between CSR commitment and operating and financial performance of firms. At the same time, an even stronger relationship, significant at a $1 \%$ level, is testified with regard to the market performance of firms with superior CSR profiles. Findings are in line with major works studying the impact of the 2007 crisis on the way 
CSR has been employed and regarded by firms and their stakeholders (Freeman 1984; Giannarakis \& Theotokas, 2011; Karaibrahimolu, 2010; Perrini et al., 2011; Souto, 2009).

In order to better explain the results, especially, in the cases of the longitudinal sample and the pre-crisis subsample, where, at least in the first case, the operating and market performance seem to improve the more sustainable practices are adopted, the financial performance of firms appears to improve, but statistically insignificantly so, for same year observations. In agreement with Hart \& Ahuja (1996), a possible explanation of this phenomenon may be that ROE, as a measure of performance also captures the firm's capital structure. Therefore, we may presume that any impact generated by improved CSR efforts faces capital structure as a confounding factor and the relationship between CSR and financial performance can result less immediate.

Table 6. Impact of "Sustainable Score” on ROA, Tobin's Q, and ROE for the entire Sample (2002-2013)

\begin{tabular}{llll}
\hline & ROA & TOBIN'S Q & ROE \\
\hline CONSTANT & 27.46 & $8.76^{* * *}$ & $109.08^{*}$ \\
R\&D INTENSITY & $(17.48)$ & $(2.06)$ & -4.68 \\
& -3.44 & $-0.36^{* * *}$ & $(3.78)$ \\
FIRM SIZE & $(3.31)$ & $(0.08)$ & $-5.54^{*}$ \\
& -1.22 & $-0.45^{* * *}$ & $(3.33)$ \\
LEVERAGE & $(1.04)$ & $(0.12)$ & 0.90 \\
& 0.11 & -0.01 & $(1.62)$ \\
EBITDA MARGIN & $(0.28)$ & $(0.00)$ & $0.04 * * *$ \\
& $0.02 * * *$ & 0.00 & $(0.01)$ \\
SUSTAINABLE SCORE & $(0.00)$ & $(0.00)$ & 1.81 \\
& $0.81 *$ & $0.11^{*}$ & $(1.34)$ \\
Fixed Effects & $(0.44)$ & $(0.06)$ & Yes \\
Industry Effects & Yes & Yes & Yes \\
Country Effects & Yes & Yes & Yes \\
Temporal Dummies & Yes & Yes & Yes \\
R2 Adjusted & Yes & Yes & 0.04 \\
Number of firms & 0.12 & 0.13 & 589 \\
Number of observations & 590 & 590 & 7,007 \\
\hline
\end{tabular}

Source: authors' elaboration.

Note: Standard errors are in the parentheses. ${ }^{*} \mathrm{p}<0.10,{ }^{* *} \mathrm{p}<0.05,{ }^{* * *} \mathrm{p}<0.01$ (two-tailed test).

Table 7. Impact of “Sustainable Score” on ROA, Tobin's Q and ROE for pre-crisis subsample (2002-2006)

\begin{tabular}{llll}
\hline & ROA & TOBIN'S Q & ROE \\
\hline CONSTANT & 29.26 & 1.58 & 42.70 \\
R\&D INTENSITY & $(42.62)$ & $(3.51)$ & $(83.87)$ \\
& $2.82^{* * *}$ & -0.10 & $2.23^{*}$ \\
FIRM SIZE & $(0.87)$ & $(0.06)$ & $(1.26)$ \\
& -1.36 & -0.02 & -2.18 \\
LEVERAGE & $(2.56)$ & $(0.21)$ & $(5.00)$ \\
& 0.25 & 0.00 & 1.01 \\
EBITDA MARGIN & $(0.32)$ & $(0.00)$ & $(1.69)$ \\
& $0.01 * * *$ & $-0.00 * * *$ & $0.02 * * *$ \\
SUSTAINABLE SCORE & $(0.00)$ & $(0.00)$ & $(0.00)$ \\
& 0.35 & $-0.07 *$ & -0.72 \\
Fixed Effects & $(0.69)$ & $(0.03)$ & $(2.00)$ \\
Industry Effects & Yes & Yes & Yes \\
Country Effects & Yes & Yes & Yes \\
Temporal Dummies & Yes & Yes & Yes \\
R2 Adjusted & Yes & Yes & Yes \\
Number of firms & 0.12 & 0.06 & 0.01 \\
Number of observations & 586 & 586 & 585 \\
\hline
\end{tabular}

Source: authors' elaboration.

Note. Standard errors are in the parentheses. ${ }^{*} \mathrm{p}<0.10,{ }^{*} \mathrm{p}<0.05, * * * \mathrm{p}<0.01$ (two-tailed test). 
Table 8. Impact of "Sustainable Score” on ROA, Tobin's Q, and ROE for post-crisis subsample (2009-2013)

\begin{tabular}{llll}
\hline & ROA & TOBIN'S Q & ROE \\
\hline CONSTANT & $42.65^{*}$ & $11.47^{* * *}$ & 34.05 \\
R\&D INTENSITY & $(21.84)$ & $(2.65)$ & $(34.75)$ \\
& $24.40^{* * *}$ & $0.77^{*}$ & $38.29^{* * *}$ \\
FIRM SIZE & $(5.64)$ & $(0.39)$ & $(2.61)$ \\
& $-2.52^{* *}$ & $-0.60^{* * *}$ & $-2.07^{*}$ \\
LEVERAGE & $(1.24)$ & $(0.15)$ & $(1.10)$ \\
& -0.69 & -0.02 & $-0.68^{* * *}$ \\
EBITDA MARGIN & $(0.47)$ & $(0.02)$ & $(0.23)$ \\
& $32.83^{* * *}$ & $0.65^{* * *}$ & $48.83^{* * *}$ \\
SUSTAINABLE SCORE & $(4.70)$ & $(0.27)$ & $(1.66)$ \\
& $0.88^{*}$ & $0.09^{* * *}$ & $1.12^{*}$ \\
Fixed Effects & $(0.51)$ & $(0.03)$ & $(0.59)$ \\
Industry Effects & Yes & Yes & Yes \\
Country Effects & Yes & Yes & Yes \\
Temporal Dummies & Yes & Yes & Yes \\
R2 Adjusted & Yes & Yes & Yes \\
Number of firms & 0.16 & 0.19 & 0.14 \\
Number of observations & 590 & 590 & 589 \\
\hline
\end{tabular}

Source: authors' elaboration.

Note. Standard errors are in the parentheses. $* \mathrm{p}<0.10, * * \mathrm{p}<0.05, * * * \mathrm{p}<0.01$ (two-tailed test).

Moving further with the analysis, we test the original decision to study the impact of holistic CSR efforts on firm performance as opposed to single-dimension approaches to CSR or potential CSR-washing and symbolic attempts. To meet such end, we examine the explanatory power of the independent variable by testing the relationship of interest against the single-dimensions of CSR that make up for the "Sustainable Score" variable (see Appendix E for details).

Table 9. Significance of individual CSR variables on ROE, ROA, Tobin's Q for sample and subsamples

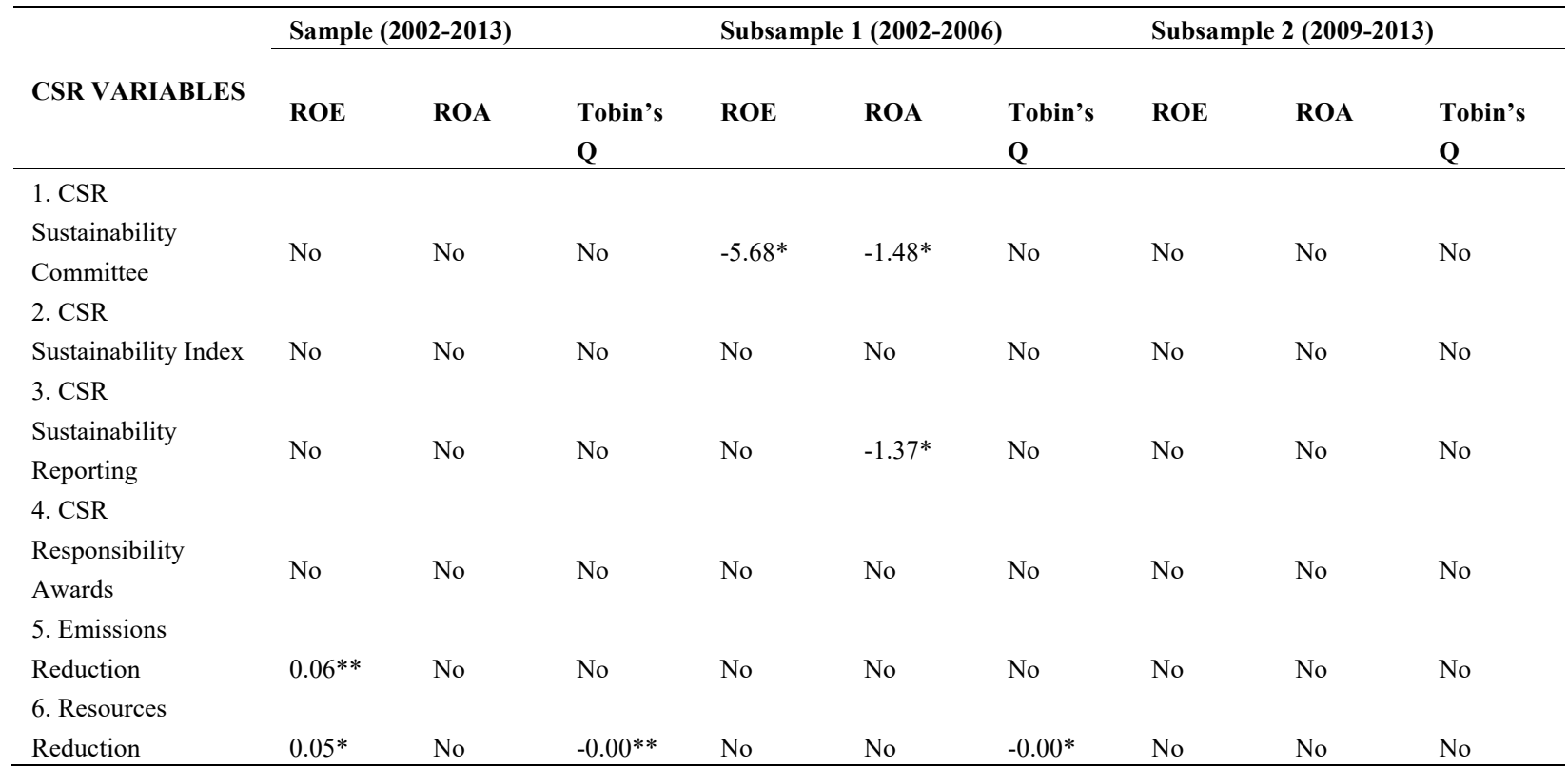

Source: authors' elaboration.

Note. Reported coefficients for the only significance found in data. $* \mathrm{p}<0.10,{ }^{* *} \mathrm{p}<0.05, * * * \mathrm{p}<0.01$ (two-tailed test).

Findings regarding the impact that single CSR dimensions have on firm performance are presented in Appendices B, C and D, while a summary of such results is given by Table 9. While the "Sustainable Score" and main independent variable of this study, employed to depict the holistic CSR stance of the firms, comes out as a strong 
influence factor of performance in the longitudinal sample and the post-crisis subsample, single CSR variables fail to produce any significant impact on CFP for any of the study's three timeframes, except for sporadic cases that lack viable interpretation.

\section{Discussion and Conclusion}

The results of this study, consistent with the prevalent literature in the field of CSR management, suggest that it does pay to be green. Better financial performance and marketability can be expected by sustainable firms relative to competitors that appear less geared towards sustainability. We, therefore, agree with Pätäri et al. (2011), that "investing in sustainable development does not have to be seen as a sacrifice or as a competing goal in relation to value creation. Instead, companies that are active in the CSR field are also generally more profitable".

Over the past decades, CSR has gained grounds as one of the most debated issues for the corporate world. Nevertheless, there are many schools of thought with respect to the real implications of CSR practices (Alberini \& Segerson, 2002; Carraro \& Siniscalco, 1996; Lyon \& Maxwell, 1999; Perrini et al., 2011; Segerson \& Li, 1999). Among scholars and practitioners in favor of a win-win CSR reality, the notion that more sustainable companies generate higher returns and achieve cost-cuttings through innovation prevails (Porter \& Kramer, 2011). In the meantime, opponents of such beliefs stay reluctant on the real association of CSR practices with the actual profitability of a firm and support a market trend approach on the matter. The latter bases CSR benefits mainly on the market's perception of a responsible company as reflected in its stock movements. As pointed out by Misani (2017), CSR has evolved into a topic that interests a vast part of society concerned with the externalities generated by firms and inflicted upon the environment and society as a whole, while research on the topic can enhance understanding of the prerequisites of CSR adoption.

We study the relationship between firm's CSR commitment and its financial performance as reflected in terms of operating, pure financial and market profile. One key contribution is the examination of CSR under a holistic approach perspective in order to decode the dynamics of the underlying relationship beyond cases of CSR-washing or merely symbolic CSR initiatives (Jahdi \& Acikdilli, 2009). Furthermore, we apply a multiple-timeframe analysis with the aim to compare and contrast observed results both in the mid and in the long-term horizon. Simultaneously, the subsamples employed in this study allow us to fill the gap in existing corporate environmental performance and corporate financial performance literature regarding the impact generated by the 2007 financial meltdown. This study supports the existence of a positive and significant relationship between effective CSR commitment and financial performance and confirms Hypotheses 1 and 2 for the longitudinal sample of the study. Opposite, Hypothesis 3 is not confirmed. More specifically, sustainable firms enjoy a higher operating performance and improved market valuations compared to their less sustainable counterparts, while such benefit is not present for returns on equity over the long-term.

Passing to the two-timeframe part of our analysis and our focus on the net impact that the crisis has generated upon the dynamics of interest, we are presenting with interesting insights regarding the observed relationship. A positive relationship between committed sustainable practices and all measures of firm performance is strongly supported by data in the post-crisis subsample. We find evidence that a robust CSR orientation can lead to operational improvements, higher ROE and richer market valuations of the firm as a whole, with an increased weight on the market appreciation of more sustainable firms. The latter provides valuable insight into the new dynamics developed after the crisis hit markets in 2007. When compared to the lower and less significant impact that CSR commitment has on performance in the sample covering the period from 2002 to 2013 and especially the null relationship indicated by the pre-crisis subsample, we can draw the conclusion, also present in relevant studies of the CSR aftermath of the crisis (Giannakaris \& Theotokas, 2011; Souto, 2009), that firms and the market took a decisive turn with respect to their view of CSR.

One plausible explanation for such conclusion can be the fact that firms needing more means to mitigate the dramatic impact of the crisis found a solid tool within the CSR framework. Sustainability moved further than a mere fashion into a realm where it is appreciated as a valid signaling instrument for corporations to demonstrate their competitive capabilities, gain additional competitive advantages and improve their capacity to meet multiple stakeholders' expectations. Furthermore, the increased intensity of the impact generated by sustainability on the market perception around firms in comparison with its impact on operational improvement and ROE within firms may also be justified by the existence of psychological biases present in the markets, especially when it comes to valuation of risk and the future value of firms' factors confounded within the operating and financial performance measures.

Delving into the pure CSR part of this study now, we adopt the holistic approach on CSR commitment and chose to 
avoid single-CSR-dimension analyses or cases of CSR-washing and symbolic CSR attempts. Findings allow us to consider that holistic CSR practices have a positive and significant impact on financial performance, a relationship that is not supported in the case of single CSR dimensions taken separately and individually. An important implication of such finding can help academics and managers realize that the mentality around CSR has matured both in the corporate world and the market and efforts are now seen with skepticism. Firms in this study tend to enjoy greater benefits when they are able to demonstrate solid and credible CSR commitment better achieved and communicated through a holistic approach rather than scattered CSR measures taken without an integrated and strategic implementation. Corporate sustainability, in fact, "is gradually being better integrated into company activities and culture" (Lozano, 2012) because there is a large number of drivers that affect the complex social organisations that are corporations, and to this purpose single sustainable dimensions often are not able to synthetize firms' efforts in term of social performance; a 360-degree sustainable approach is called for, as pointed out by the theorists of CSR holistic approach. Findings are coherent with previous results in this filed, in fact Orlitzky \& Benjamin (2001), highlighted that benefits deriving from strong sustainable practices are strongly correlated with market-based measures than operating-based measures.

Concluding our work, we cannot help but find several fields where future research can shed more light upon. Further work can always examine the reverse causality effect: do stronger CSR-wise activities lead to enhanced profitability or do more profitable companies tend to invest in more sustainable activities? In our case, no industry selection has been performed, giving rise to an interest in future obtained results through studies with an industry focus to explore whether the relationship investigated here appears less or more significant, practices alter, and time lags are different. What is more, different studies can employ different metrics to operationalize CSR performance based on even more CSR dimensions, as well focusing on the idiosyncratic CSR adjustments of specific industries or geographic areas and time periods.

Finally, it may prove of great potential researching the risk associated to CSR practices: do all combinations of CSR practices generate benefits or they need to be adjusted to the firm, industry or market?

\section{References}

Aguinis, H., \& Glavas, A. (2012). What we know and don't know about Corporate Social Responsibility: A review and research agenda. Journal of Management, 20, 932-968. https://doi.org/10.1177/0149206311436079

Alberini, A., \& Segerson, K. (2002). Assessing Voluntary Programs to Improve Environmental Quality. Environmental and Research Economics, 22, 157-184. https://doi.org/10.1023/A:1015519116167

Allegrini, M., \& Greco, G. (2011). Corporate boards, audit committees and voluntary disclosure: evidence from Italian Listed Companies. Journal of Management and Governance, 17, 1-30. https://doi.org/10.1007/s10997-011-9168-3

Alves, I. (2009). Green spin everywhere: how greenwashing reveals the limits of the CSR paradigm. Journal of Global Change and Governance, 2, 1-26. https://doi.org/10.1.1.458.3293

Arlow, P., \& Gannon, M. J. (1982). Social responsiveness, corporate structure, and economic performance. Academy of Management Review, 72, 235-241. https://doi.org//abs/10.5465/amr.1982.4285580

Bansal, P. (2005). Evolving sustainably: A longitudinal study of corporate sustainable development. Strategic Management Journal, 26, 197-218. https://doi.org/10.1002/smj.441

Barnett, M. (2007). Stakeholder influence capacity and the variability of financial returns to corporate social responsibility. Academy of Management Review, 32, 794-816. https://doi.org/abs/10.5465/amr.2007.25275520

Barnett, M., \& Salomon, R. (2012). Does it pay to be really good? Addressing the shape of the relationship between social and financial performance. Strategic Management Journal, 33, 1304-1320. https://doi.org/10.1002/smj.1980

Barney, J. (1991). Firm resources and sustained competitive advantage. Journal of Management, 17, 99-120. https://doi.org/10.1177/014920639101700108

Benninga, S. (2008). Financial Modelin (3rd ed.). The MIT Press Cambridge, Massachusetts London, England.

Berchicci, L., \& King, A. (2007). 11 postcards from the edge: a review of the business and environment literature. Academy of Management Annals, 1, 513-547. https://doi.org/10.1080/078559816

Boulding, K. (1956). General systems theory: the skeleton of science. Management Science, 2, 197-208. https://doi.org/abs/10.1287/mnsc.2.3.197 
Bragdon, J., \& Marlin, J. (1972). Is pollution profitable? Risk Management, 19, 9-18.

Brundtland, G. (1987). Our Common Future. World Commission on Environment and Development: Brussels.

Burhan, A., \& Rahmanti, W. (2009). The impact of sustainability reporting on company performance. Journal of Economics, Business and Accountancy, 15, 257-272. https://doi.org/10.14414/jebav.v15i2.79

Carraro, C., \& Siniscalco, D. (1996). Voluntary Agreements in Environmental Policy: A Theoretical Appraisal. In A. Xepapadeas, ed., Economic Policy for the Environment and Natural Resources. E. Elgar, Oxford.

Chan, P., \& Walter, T. (2014). Investment performance of environmentally-friendly firms and their initial public offers and seasoned equity offers. Journal of Banking and Finance, 44, 177-188. https://doi.org/10.1016/j.jbankfin.2014.04.006

Chang, Y. (2016). Moderating Effects of Media Coverage and Corporate Governance on CSR-CFP Nexus-Evidence from Listed Companies on Taiwan Stock Exchange. International Journal of Economics and Finance, 8, 190-211. http://dx.doi.org/10.5539/ijef.v8n5p190

Christmann, P. (2000). Effects of Best Practices of Environmental Management on Cost Advantage: The Role of Complementary Assets. Academy of Management Journal, 43, 663-680. https://journals.aom.org/doi/abs/10.5465/1556360

Cinquini, L., Passetti, E., Tenucci, A., \& Frey, M. (2012). Analyzing intellectual capital information in sustainability reports: some empirical evidence. Journal of Intellectual Capital, 13, 531-561. https://doi.org/10.1108/14691931211276124

Dallocchio, M., \& Salvi, A. (2011). Finanza Aziendale. Finanza Ordinaria e Finanza Straordinaria. Egea, Milano.

Dang, C., \& Li, F. (2015). Measuring firm size in empirical corporate finance. Mimeo, University of Western Ontario.

Dowell, G., Hart, S., \& Yeung, B. (2000). Do Corporate Global Environmental Standards Create or Destroy Market Value? Management Science, 46, 1059-1074. https://doi.org/10.1287/mnsc.46.8.1059.12030

Dumitrescu, D., \& Simionescu, L. (2013). Empirical Research Regarding the Influence of Corporate Social Responsibility (CSR) Activities on Companies' Employees and Financial Performance. The Bucharest University of Economic Studies, 49, 52-66.

Dyllick, T., \& Hockerts, K. (2002). Beyond the Business Case for Corporate Sustainability. Business Strategy and the Environment, 11, 130-141. https://doi.org/10.1002/bse.323

Ellis, L., \& Bastin, C. (2011). Corporate Social Responsibility in Times of Recession: Changing Discourses and Implications for Policy and Practice. Corporate Social Responsibility and Environmental Management, 18, 294-305. https://doi.org/10.1002/csr.254

Endrikat, J. (2015). Market Reactions to Corporate Environmental Performance Related Events: A Meta-Analytic Consolidation of the Empirical Evidence. Journal of Business Ethics, 138, 535-548. https://doi.org/10.1007/s10551-015-2598-0

Freeman, R. (1984). Strategic Management. A stakeholder Approach. Pitman/Ballinger (Harper Collins): Boston.

Freeman, R., \& Velamuri, S. (2006). A new approach to CSR: Company stakeholder responsibility. In A. Kakabadse and M. Morsing (Eds.), Corporate social responsibility: Reconciling aspiration with application (pp. 9-23). Houndmills, Basingstoke, UK: Palgrave Macmillan.

Friedman, M. (1970). The social responsibility of business is to increase its profits. New York Times Magazine. Reprinted from Perspectives in business ethics (3rd ed., pp. 280-285). New York, NY: McGraw-Hill.

Garcia-Castro, R., Arino, M., \& Canela, M. (2010). Does Social Performance Really Lead to Financial Performance? Accounting for Endogeneity. Journal of Business Ethics, 92, 107-126. https://doi.org/10.1007/s10551-009-014-8

Giannarakis, G., \& Theotokas, I. (2011). The Effect of Financial Crisis in Corporate Social Responsibility Performance. International Journal of Marketing Studies, 3, 2-10. http://dx.doi.org/10.5539/ijms.v3n1p2

Godfrey, P., Merrill, C., \& Hansen, J. (2009). The relationship between corporate social responsibility and shareholder value: an empirical test of the risk management hypothesis. Strategic Management Journal, 30,. 225-245. https://doi.org/10.1002/smj.750 
Golicic, S., \& Smith, C. (2013). A meta-analysis of environmentally sustainable supply chain management practices and firm performance. Journal of Supply Chain Management, 49, 78-95. https://doi.org/10.1111/jscm.12006

González-Benito, J., \& González-Benito, O. (2005). Environmental proactivity and business performance: An empirical analysis. Omega, 33, 1-15. https://doi.org/ 10.1016/j.omega.2004.03.002.

Gregory, A., \& Whittaker, J. (2012). Exploring the Valuation of Corporate Social Responsibility-A comparison of Research Methods. Journal of Business Ethics, 116, 1-20. https://doi.org/10.1007/s10551-012-1465-5

Griffin, J., \& Mahon, J. (1997). The Corporate Social Performance and Corporate Financial Performance Debate. Business \& Society, 36, 5-31. https://doi.org/10.1177/000765039703600102

Hart, S., \& Ahuja, G. (1996). Does it pay to be green? An empirical examination of the relationship between emission reduction and firm performance. Business Strategy and the Environmental, 5, 30-37. https://doi.org/10.1002/(SICI)1099-0836(199603)5:1<30:AID-BSE38>3.0.CO;2-Q

Hassel, L., Nilsson, H., \& Nyquist, S. (2005). The value relevance of environmental performance. European Accounting Review, 14, 41-61. https://doi.org/10.1080/0963818042000279722

Heras-Saizarbitoria, I., Molina-Azorín, J., \& Dick, G. (2011). ISO 14001 certification and financial performance: selection-effect versus treatment-effect. Journal of Cleaner Production, 19, 1-12. http://doi.org/10.1016/j.jclepro.2010.09

Hoepner, G., Yu, P., \& Ferguson, J. (2010). Corporate Social Responsibility among Industries: When can who do well by doing good? Social Science Research Network. SSRN e-library. http://dx.doi.org/10.2139/ssrn.1284703

Horváthová, E. (2010). Does environmental performance affect financial performance? A meta-analysis. Ecological Economics, 70, 52-59. https://doi.org/10.1016/j.ecolecon.2010.04.004

Jahdi, K., \& Acikdilli, G. (2009). G. Marketing Communications and Corporate Social Responsibility (CSR): Marriage of Convenience or Shotgun Wedding? Journal of Business Ethics, 88, 88-103. https://doi.org/10.1007/s10551-009-0113-1.

Jensen, M. (2001). Value maximization, stakeholder theory, and the corporate objective function. Journal of Applied Corporate Finance, 14, 8-21. https://doi.org/10.1111/j.1745-6622.2001.tb00434.x

Karaibrahimolu, Y. (2010). Corporate social responsibility in times of financial crisis. African Journal of Business Management, 4, 382-389.

Khanna, M., \& Damon, L. (1999). EPA's Voluntary 33/50 Program: Impact on Toxic Releases and Economic Performance of Firms. Journal of Environmental Economics and Management, 37, 1-25. https://doi.org/10.1006/jeem.1998.1057

Kim, Y., Li, H., \& Li, S. (2014). Corporate social responsibility and stock price crash risk. Journal of Banking \& Finance, 43, 1-13. https://doi.org/10.1016/j.jbankfin.2014.02.013

King, A., \& Lenox, M. (2001). Does It Really Pay to Be Green? An Empirical Study of Firm Environmental and Financial Performance. Journal of Industrial Ecology, 5, 105-116. https://doi.org/10.1162/108819801753358526

King, A., \& Lenox, M. (2002). Exploring the locus of profitable pollution reduction. Management Science, 48, 289-299. https://doi.org/10.1287/mnsc.48.2.289.258

Klassen, R., \& McLaughlin, C. (1996). The Impact of Environmental Management on Firm Performance. Management Science, 42, 1199-1214. https://doi.org/10.1287/mnsc.42.8.1199

Konar, S., \& Cohen, M. (2001). Does the market value environmental performance? Review of Economics and Statistics, 83, 281-289. http://dx.doi.org/10.1162/00346530151143815

KPMG. (2008). KPMG International survey of responsibility reporting 2008. Amstelveen. The Netherlands: KPMG International.

Lech, A. (2013). Corporate Social Responsibility and Financial Performance. Theoretical and Empirical Aspects. Comparative Economic Research, 16, 49-62. https://doi.org/10.2478/cer-2013-0018

Li, Y., Wu, K., \& Ding, M. (2013). Doing Good Does Good? Sustainable Marketing of CSR and Consumer Evaluations. Corporate Social Responsibility and Environmental Management, 20, 15-28. https://doi.org/10.1002/csr.294 
Lindenberg, E., \& Ross, S. (1981). Tobin's q ratio and industrial organization. Journal of Business, 54, 1-32. http://dx.doi.org/10.1086/296120

Link, S., \& Naveh, E. (2006). Standardization and Discretion: Does the Environmental Standard ISO 14001 Lead to Performance Benefits? IEEE Transactions on Engineering Management, 53, 508-519. https://doi.org/10.1109/TEM.2006.883704

Lourenço, I., Branco, M., Curto, J., \& Eugenio, T. (2012). How Does the Market Value Corporate Sustainability Performance? Journal of Business Ethics, 108, 417-428. https://doi.org/10.1007/s10551-011-1102-8

Lozano, R. (2012). Are companies planning their organisational changes for Corporate Sustainability? An analysis of three case studies on resistance to change and their strategies to overcome it. Corporate Social Responsibility and Environmental Management, 20, 275-295. https://doi.org/10.1002/csr.1290

Lozano, R. (2013). A Holistic Perspective on Corporate Sustainability Drivers. Corporate Social Responsibility and Environmental Management, 22, 32-44. https://doi.org/10.1002/csr.1325

Lyon, T., \& Maxwell, J. (1999). Voluntary Approaches to Environmental Regulation: A Survey. Social Science Research Network (SSRN). https://ssrn.com/abstract=234610

Margolis, J., \& Walsh, J. (2001). People and Profits? Lawrence Erlbaum Associates, New Jersey.

Margolis, J., \& Walsh, J. (2003). Misery Loves Companies: Rethinking Social Initiatives by Business. Administrative Science Quarterly, 48, 268-305. https://doi.org/10.2307/3556659

Margolis, J., Elfenbein, H., \& Walsh, J. (2007). Does it pay to be good? A meta-analysis and redirection of research on the relationship between corporate social and financial performance. University of Michigan, Ann Arbor, 1001, 48109-1234. https://doi.org/10.2139/ssrn.186637

McGuire, K., Sungren, A., \& Schneeweis, T. (1988). Corporate Social Responsibility and Firm Performance. Academy of Management Journal, 31, 854-872. https://journals.aom.org/doi/abs/10.5465/256342

McWilliams, A., \& Siegel, D. (2001). Corporate social responsibility: a theory of the firm perspective. Academy of Management Review, 26, 117-127. https://doi.org/10.2307/259398

Mills, L. (2014). Global trends in clean energy investment. Bloomberg New Energy Finance, Annual Report.

Mirvis, P., \& Googins, B. (2006). Stages of Corporate Citizenship. California Management Review, 48, 104-126. https://doi.org/10.2307/41166340

Misani, N. (2017). The Organizational Outcomes of Corporate Social Responsibility: A Review of the Literature. https://ssrn.com/abstract $=2968787$

Nakamura, E. (2011). Does environmental investment really contribute to firm performance? An empirical analysis using Japanese firms. Eurasian Business Review, 1, 91-111. https://doi.org/10.14208/BF03353800

Nelling, E., Webb, E. (2008). Corporate Social Responsibility and Financial Performance: The "Virtuous Circle" revisited. Review of Quantitative Finance and Accounting, 32, 197-209. https://doi.org/10.1177/0007650315590399

Nelson, K. (1994). Finding and implementing projects that reduce waste, Industrial ecology and global change. New York: Cambridge University Press.

Nollet, J., Filis, G., \& Mitrokostas, E. (2015). Corporate Social Responsibility and Financial Performance: A non-linear and disaggregated approach. Economic Modelling, 52, 400-407. https://doi.org/10.1016/j.econmod.2015.09.019

Orlitzky, M., Schmidt, F. L., \& Rynes, S. L. (2003). Corporate social and financial performance: A meta-analysis. Organization Studies, 24, 403-441. https://doi.org/10.1177/0170840603024003910

Ortas, E., Alvarez, I., Jaussaud, J., Garayar, A. (2015). The impact of institutional and social context on corporate environmental, social and governance performance of companies committed to voluntary corporate social responsibility initiatives. Journal of Cleaner Production, 30, 1-12. https://doi.org/10.1016/j.jclepro.2015.06.089

Passetti, E., Tenucci, A., Cinquini, L., \& Frey, M. (2009). Intellectual Capital Communication: Evidence from Social and Sustainability Reporting. http://dx.doi.org/10.2139/ssrn.1443163

Pätäri, S., Jantunen, A., Kylaheiko, K., \& Sandstrom, J. (2011). Does Sustainable Development Foster Value Creation? Empirical Evidence from the Global Energy Industry. Corporate Social Responsibility and 
Environmental Management, 19, 317-326. https://doi.org/10.1002/csr.280

Perrini, F., Russo, A., Tencati, A., \& Vurro, C. (2011). Deconstructing the Relationship Between Corporate Social and Financial Performance. Journal of Business Ethics, 102, 59-76. https://doi.org/10.1007/s10551-011-1194-1

Pope, S., \& Wæraas, A. (2016). CSR-Washing is Rare: A Conceptual Framework, Literature Review, and Critique. Journal of Business Ethics, 137, 173-193. https://doi.org/10.1007/s10551-015-2546-Z

Porter, M., \& Kramer, M. (2011). Creating Shared Value: How to reinvent capitalism and unleash a wave of innovation and growth. Harvard Business Review, 63-70.

Porter, M., \& Van der Linde, C. (1995). Toward a New Conception of the Environment-Competitiveness Relationship. Journal of Economic Perspectives, 9, 97-118. https://doi.org/10.1257/jep.9.4.97

Post, J., Preston, L., \& Sachs, S. (2002). Managing the Extended Enterprise: The New Stakeholder View. California Management Review, 45, 6-28. https://doi.org/10.2307/41166151

Rangan, V., Chase, L., \& Karim, S. (2015). The Truth about CSR. Harvard Business Review, 93, 40-49.

Robb, S., Single, L., \& Zarzeski, M. (2001). Nonfinancial disclosures across Anglo-American countries. Journal of International Accounting, Auditing and Taxation, 10, 71-83. https://doi.org/10.1016/S1061-9518(01)00036-2

Roman, R., Hayibor, S., Agle, B. (1999). The Relationship between Social and Financial Performance. Business \& Society, 38, 109-125. https://doi.org/10.1177/000765039903800105

Rosewicz, B. (1990). Americans Are Willing to Sacrifice to Reduce Pollution, They Say. The Wall Street Journal, A1.

Russell, C., Russell, D., \& Honea, H. (2016). Corporate Social Responsibility Failures: How do Consumers Respond to Corporate Violations of Implied Social Contracts? Journal of Business Ethics, 136, 759-773. https://doi.org/10.1007/s10551-015-2868-x

Russo, M., \& Fouts, P. (1997). A Resource-Based Perspective on Corporate Environmental Performance and Profitability. Academy of Management Journal, 40, 534-559. https://journals.aom.org/doi/abs/10.5465/257052

Santoso, A., \& Feliana, Y. (2014). The Association between Corporate Social Responsibility and Corporate Financial Performance. Issues in Social and Environmental Accounting, 8, 82-103. https://doi.org/10.22164/isea.v8i2.86.

Segerson, K., \& Li, N. (1999). Voluntary Approaches to Environmental Protection. The International Yearbook of Environmental and Resource Economics, 273-306.

Semenova, N., \& Hassel, L. (2014). On the validity of environmental performance metrics. Journal of Business Ethics, 132, 1-10. https://doi.org/10.1007/s10551-014-2323-4

Souto, B. (2009). Crisis and Corporate Social Responsibility: Threat or Opportunity? International Journal of Economic Sciences and Applied Research, 2, 36-50. https:/handle/10419/66605

Stock, J., \& Watson, M. (2005). Introduction to Econometrics (1st ed.). Pearson \& publishing as A.-W. Education, Inc,

Tang, Z., Hull, C., \& Rothenberg, S. (2012). How Corporate Social Responsibility Engagement Strategy Moderates the CSR-Financial Performance Relationship. Journal of Management Studies, 49, 1274-1303. https://doi.org/10.1111/j.1467-6486.2012.01068.x

Ullmann, A. (1985). Data in Search of a Theory: A Critical Examination of the Relationships among Social Performance, Social Disclosure, and Economic Performance of U.S. Firms. Academy of Management Review, 10, 540-557. https://doi.org/10.5465/AMR.1985.4278989

Waddock, S. A. (2004). Parallel universes: Companies, academics, and the progress of corporate citizenship. Business and Society Review, 109, 5-42. https://doi.org/10.1111/j.0045-3609.2004.00002.x

Waddock, S. A., \& Graves, S. B. (1997). The corporate social performance-financial performance link. Strategic $\begin{array}{llll}\text { Management } \quad \text { Journal, } & \text { 303-319. }\end{array}$ https://doi.org/10.1002/(SICI)1097-0266(199704)18:4<303::AID-SMJ869>3.0.CO;2-G

Wagner, M. (2005). How to reconcile environmental and economic performance to improve corporate 
sustainability: corporate environmental strategies in the European paper industry. Journal of Environmental Management, 76, 105-118. https://doi.org/ 10.1016/j.jenvman.2004.11.021

Walker, K., \& Wan, F. (2012). The Harm of Symbolic Actions and Green-Washing: Corporate Actions and Communications on Environmental Performance and Their Financial Implication. Journal of Business Ethics, 109, 227-242. https://doi.org/10.1007/s10551-011-1122-4

Wang, Q., Dou, J., \& Jia, S. (2015). A Meta-Analytic Review of Corporate Social Responsibility and Corporate Financial Performance: The Moderating Effect of Contextual Factors. Business \& Society, 55, 1083-1121. https://doi.org/10.1177/0007650315584317

Wang, Y., \& Berens, G. (2014). The Impact of Four Types of Corporate Social Performance on Reputation and Financial Performance. Journal of Business Ethics, 131, 337-359. https://doi.org/10.1007/s10551-014-2280-y

Wood D. (2010). Measuring Corporate Social Performance: A Review. International Journal of Management Reviews, 12, 50-84. https://doi.org/10.1111/j.1468-2370.2009.00274.x

$\mathrm{Wu}$, J. (2014). The antecedents of Corporate Social and Environmental Irresponsibility. Corporate Social Responsibility and Environmental Management, 21, 286-300. https://oi.org/10.1002/csr.1335

Zygadlo, K., Slonski, T., Zawadzki, B. (2016). The Market Value of CSR Performance across Sectors. Inzinerine Ekonomika-Engineering Economics, 27, 230-238. http://dx.doi.org/10.5755/j01.ee.27.2.13480

\section{Notes}

Note 1 . The S\&P Global 1200 provides efficient exposure to the global equity market. Capturing approximately $70 \%$ of global market capitalization, it is constructed as a composite of 7 headline indices, many of which are accepted leaders in their regions. These include the S\&P 500® (US), S\&P Europe 350, S\&P TOPIX 150 (Japan), S\&P/TSX 60 (Canada), S\&P/ ASX All Australian 50, S\&P Asia 50 and S\&P Latin America 40. (Source: http://us.spindices.com/indices/equity/sp- global-1200).

Note 2. Total Assets represent the sum of total current assets, long-term receivables, investment in unconsolidated subsidiaries, other investments, net property plant and equipment and other assets.

Note 3. Market value is the share price multiplied by the number of ordinary shares in issue. The amount in issue is updated whenever new tranches of stock are issued or after a capital change.

Note 4. Net Income - bottom line represents income after all operating and non-operating income and expense, reserves, income taxes, minority interest and extraordinary items.

Note 5. Common Equity represents common shareholders' investment in a company.

Note 6. Net Sales or Revenues represent gross sales and other operating revenue less discounts, returns and allowances.

Note 7. Earnings Before Interest, Taxes and Depreciation (EBITDA) represent the earnings of a company before interest expense, income taxes and depreciation. It is calculated by taking the pretax income and adding back interest expense on debt and depreciation, depletion and amortization, while subtracting interest capitalized.

\section{Appendix}

Appendix A. Variance Inflation Factor (VIF) test - sample and two subsamples

\begin{tabular}{llll}
\hline VARIABLES & Sample & Subsample 1 & Subsample 2 \\
& $(\mathbf{2 0 0 2 - 2 0 1 3 )}$ & $\mathbf{( 2 0 0 2 - 2 0 0 6 )}$ & VIF \\
\hline & VIF & VIF & 1.59 \\
R\&D INTENSITY & 1.00 & 1.01 & 1.05 \\
FIRM SIZE & 1.06 & 1.05 & 1.02 \\
LEVERAGE & 1.00 & 1.00 & 1.60 \\
EBITDA MARGIN & 1.00 & 1.00 & 1.03 \\
SUSTAINABLE SCORE & 1.05 & 1.04 & $\mathbf{1 . 2 6}$ \\
MEAN VIF & $\mathbf{1 . 0 2}$ & $\mathbf{1 . 0 2}$ & \\
\hline
\end{tabular}

Source: authors' elaboration. 
Appendix B: Impact of single Sustainability Score dimensions on financial performance: sample (2002-2013)

Table 10. CSR sustainability committee

\begin{tabular}{llll}
\hline & ROE & ROA & TOBIN'S Q \\
\hline Constant & $161.31^{* *}$ & $60.69^{* * *}$ & $11.17^{* * *}$ \\
R\&D INTENSITY & $(76.26)$ & $(13.20)$ & $(2.82)$ \\
& $-20.73^{* * *}$ & $-17.92^{* * *}$ & -0.16 \\
FIRM SIZE & $(3.95)$ & $(2.65)$ & $(0.16)$ \\
& $-9.23^{* *}$ & $-3.17^{* * *}$ & $-0.59^{* * *}$ \\
LEVERAGE & $(4.68)$ & $(0.79)$ & $(0.17)$ \\
& 0.67 & 0.12 & -0.01 \\
EBITDA MARGIN & 1.70 & $(0.30)$ & $(0.00)$ \\
& $0.04^{* * *}$ & $0.21^{* * *}$ & 0.00 \\
CSR SUSTAINABILITY COMMITTEE & $(0.01)$ & $(0.00)$ & $(0.00)$ \\
& 2.56 & 0.11 & 0.07 \\
Fixed Effects & $(2.20)$ & $(0.45)$ & $(0.05)$ \\
Dummy Year & Yes & Yes & Yes \\
Dummy Country & Yes & Yes & Yes \\
Dummy Industry & Yes & Yes & Yes \\
Adjusted R & Yes & Yes & Yes \\
Number of firms & 0.05 & 0.14 & 0.13 \\
Number of observations & 589 & 590 & 590 \\
\hline
\end{tabular}

Source: authors' elaboration.

Note. Standard errors are in the parentheses. ${ }^{*} \mathrm{p}<0.10,{ }^{*} \mathrm{p}<0.05, * * * \mathrm{p}<0.01$ (two-tailed test).

Table 11. CSR sustainability index

\begin{tabular}{|c|c|c|c|}
\hline & ROE & ROA & TOBIN'S Q \\
\hline \multirow[t]{2}{*}{ Constant } & $161.56^{* *}$ & $60.62 * * *$ & $11.15 * * *$ \\
\hline & $(75.84)$ & $(16.18)$ & $(2.80)$ \\
\hline \multirow[t]{2}{*}{ R\&D INTENSITY } & $-20.86 * * *$ & $-17.93 * * *$ & 0.16 \\
\hline & $(4.05)$ & $(2.65)$ & $(0.16)$ \\
\hline \multirow[t]{2}{*}{ FIRM SIZE } & $-9.22 * *$ & $-3.17 * * *$ & $-0.59 * * *$ \\
\hline & $(4.66)$ & $(0.69)$ & $(0.17)$ \\
\hline \multirow[t]{2}{*}{ LEVERAGE } & 0.66 & -0.12 & $0.01 *$ \\
\hline & $(1.70)$ & $(0.30)$ & $(0.00)$ \\
\hline \multirow[t]{2}{*}{ EBITDA MARGIN } & $0.04 * * *$ & $0.02 * * *$ & 0.00 \\
\hline & $(0.01)$ & $(0.00)$ & $(0.00)$ \\
\hline \multirow[t]{2}{*}{ CSR SUSTAINABILITY INDEX } & -0.31 & 0.16 & 0.06 \\
\hline & $(2.12)$ & $(0.46)$ & $(0.06)$ \\
\hline Fixed Effects & Yes & Yes & Yes \\
\hline Dummy Year & Yes & Yes & Yes \\
\hline Dummy Country & Yes & Yes & Yes \\
\hline Dummy Industry & Yes & Yes & Yes \\
\hline Adjusted R & 0.05 & 0.14 & 0.12 \\
\hline Number of firms & 589 & 590 & 590 \\
\hline Number of observations & 6,383 & 6,359 & 6,359 \\
\hline
\end{tabular}

Source: authors' elaboration.

Note. Standard errors are in the parentheses. $* \mathrm{p}<0.10, * * \mathrm{p}<0.05, * * * \mathrm{p}<0.01$ (two-tailed test). 
Table 12. CSR sustainability reporting

\begin{tabular}{llll}
\hline & ROE & ROA & TOBIN'S Q \\
\hline Constant & $160.61^{* *}$ & $60.66^{* * *}$ & $11.14^{* * *}$ \\
R\&D INTENSITY & $(75.61)$ & $(13.20)$ & $(2.79)$ \\
& $-20.76^{* * *}$ & $-17.93^{* * *}$ & -0.16 \\
FIRM SIZE & $(4.01)$ & $(2.65)$ & $(0.16)$ \\
& $-9.17^{* *}$ & $-3.17^{* * *}$ & $-0.59^{* * *}$ \\
LEVERAGE & $(4.64)$ & $(0.79)$ & $(0.17)$ \\
& 0.67 & 0.12 & $-0.00^{*}$ \\
EBITDA MARGIN & $(1.70)$ & $(0.30)$ & $(0.00)$ \\
& $0.04^{* * *}$ & $0.02^{* * *}$ & 0.00 \\
CSR SUSTAINABILITY & $(0.01)$ & $(0.00)$ & $(0.00)$ \\
REPORTING & 2.60 & 0.10 & 0.13 \\
Fixed Effects & $(2.48)$ & $(0.44)$ & $(0.09)$ \\
Dummy Years & Yes & Yes & Yes \\
Dummy Country & Yes & Yes & Yes \\
Dummy Industry & Yes & Yes & Yes \\
Adjusted R & Yes & Yes & Yes \\
Number of firms & 0.05 & 0.14 & 0.12 \\
Number of observations & 589 & 590 & 590 \\
\hline
\end{tabular}

Source: authors' elaboration.

Note. Standard errors are in the parentheses. ${ }^{*} \mathrm{p}<0.10,{ }^{* *} \mathrm{p}<0.05,{ }^{* * *} \mathrm{p}<0.01$ (two-tailed test).

Table 13. CSR responsibility awards

\begin{tabular}{llll}
\hline & ROE & ROA & TOBIN'S Q \\
\hline Constant & $162.18^{* *}$ & $60.98^{* * *}$ & $11.17^{* * *}$ \\
R\&D INTENSITY & $(76.61)$ & $(13.24)$ & $(2.81)$ \\
& $-20.84^{* * *}$ & $-17.90^{* * *}$ & 0.17 \\
FIRM SIZE & $(4.01)$ & $(2.62)$ & $(0.17)$ \\
& $-9.29^{* *}$ & $-3.19^{* * *}$ & $-0.59^{* * *}$ \\
LEVERAGE & $(4.70)$ & $(3.79)$ & $(0.17)$ \\
& 0.67 & 0.13 & $0.01^{*}$ \\
EBITDA MARGIN & $(1.60)$ & $(0.30)$ & $(0.00)$ \\
& $0.04^{* * *}$ & $0.02^{* * *}$ & 0.00 \\
CSR RESPONSIBILITY AWARDS & $(0.01)$ & $(0.00)$ & $(0.00)$ \\
& 1.13 & 0.30 & -0.02 \\
Fixed Effects & $(0.83)$ & $(0.28)$ & $(0.03)$ \\
Dummy Years & Yes & Yes & Yes \\
Dummy Country & Yes & Yes & Yes \\
Dummy Industry & Yes & Yes & Yes \\
Adjusted R & Yes & Yes & Yes \\
Number of firms & 0.05 & 0.14 & 0.13 \\
Number of observations & 589 & 590 & 590 \\
\hline
\end{tabular}

Source: authors' elaboration.

Note. Standard errors are in the parentheses. ${ }^{*} \mathrm{p}<0.10,{ }^{* *} \mathrm{p}<0.05,{ }^{* * *} \mathrm{p}<0.01$ (two-tailed test). 
Table 14. Emissions reduction

\begin{tabular}{llll}
\hline & ROE & ROA & TOBIN'S Q \\
\hline Constant & $161.24^{* *}$ & $60.68^{* * *}$ & $11.17^{* * *}$ \\
R\&D INTENSITY & $(76.31)$ & $(13.20)$ & $(2.82)$ \\
& $-20.73^{* * *}$ & $-17.91^{* * *}$ & -0.17 \\
FIRM SIZE & $(3.96)$ & $(2.64)$ & $(0.17)$ \\
& $-9.39^{* *}$ & $-3.21^{* * *}$ & $-0.59^{* * *}$ \\
LEVERAGE & $(4.73)$ & $(0.80)$ & $(0.17)$ \\
& 0.66 & 0.12 & $-0.01^{*}$ \\
EBITDA MARGIN & $(1.69)$ & $(0.30)$ & $(0.00)$ \\
& $0.04^{* * *}$ & $0.02^{* * *}$ & 0.00 \\
EMISSIONS REDUCTION & $(0.01)$ & $(0.00)$ & $(0.00)$ \\
& $0.06^{* *}$ & 0.01 & 0.00 \\
Fixed Effects & $(0.03)$ & $(0.01)$ & $(0.00)$ \\
Dummy Years & Yes & Yes & Yes \\
Dummy Country & Yes & Yes & Yes \\
Dummy Industry & Yes & Yes & Yes \\
Adjusted R & Yes & Yes & Yes \\
Number of firms & 0.05 & 0.14 & 0.12 \\
Number of observations & 589 & 590 & 590 \\
\hline
\end{tabular}

Source: authors' elaboration.

Note. Standard errors are in the parentheses. ${ }^{*} \mathrm{p}<0.10,{ }^{* *} \mathrm{p}<0.05,{ }^{* * *} \mathrm{p}<0.01$ (two-tailed test).

Table 15. Resources Reduction

\begin{tabular}{llll}
\hline & ROE & ROA & TOBIN'S Q \\
\hline Constant & $163.84^{* *}$ & $60.46^{* * *}$ & $11.08^{* * *}$ \\
R\&D INTENSITY & $(76.84)$ & $(13.19)$ & $(2.80)$ \\
& $-20.75^{* * *}$ & $-17.94^{* * *}$ & -0.17 \\
FIRM SIZE & $(3.97)$ & $(2.66)$ & $(0.17)$ \\
& $-9.51^{* *}$ & $-3.14^{* * *}$ & $-0.58^{* * *}$ \\
LEVERAGE & $(4.74)$ & $(0.79)$ & $(0.16)$ \\
& 0.66 & 0.13 & -0.00 \\
EBITDA MARGIN & $(1.70)$ & $(0.30)$ & $(0.00)$ \\
& $0.04^{* * *}$ & $0.02^{* * *}$ & 0.00 \\
RESOURCES REDUCTION & $(0.01)$ & $(0.00)$ & $(0.00)$ \\
& $0.05^{*}$ & -0.00 & $-0.00^{* *}$ \\
Fixed Effects & $(0.03)$ & $(0.00)$ & $(0.00)$ \\
Dummy Years & Yes & Yes & Yes \\
Dummy Country & Yes & Yes & Yes \\
Dummy Industry & Yes & Yes & Yes \\
Adjusted R & Yes & Yes & Yes \\
Number of firms & 0.05 & 0.14 & 0.13 \\
Number of observations & 589 & 590 & 590 \\
\hline
\end{tabular}

Source: authors' elaboration.

Note. Standard errors are in the parentheses. ${ }^{*} \mathrm{p}<0.10,{ }^{* *} \mathrm{p}<0.05,{ }^{* * *} \mathrm{p}<0.01$ (two-tailed test).

APPENDIX C: Impact of single Sustainability Score dimensions on financial performance: pre-crisis subsample (2002-2006) 
Table 16. CSR sustainability committee

\begin{tabular}{llll}
\hline & ROE & ROA & TOBIN'S Q \\
\hline Constant & 112.35 & $125.20^{* * *}$ & 3.83 \\
R\&D INTENSITY & $(110.06)$ & $(37.37)$ & $(5.18)$ \\
& -34.44 & $-75.88^{* * *}$ & $-7.88^{* * *}$ \\
FIRM SIZE & $(68.50)$ & $(27.37)$ & $(2.20)$ \\
& -6.25 & $-6.94 * * *$ & -0.13 \\
LEVERAGE & $(6.44)$ & $(2.27)$ & $(0.31)$ \\
& 0.76 & 0.27 & 0.00 \\
EBITDA MARGIN & $(1.76)$ & $(0.34)$ & $(0.00)$ \\
& $0.03 * * *$ & $0.01 * * *$ & $-0.00^{* *}$ \\
CSR SUSTAINABILITY & $(0.00)$ & $(0.00)$ & $(0.00)$ \\
COMMITTEE & $-5.68^{*}$ & $-1.48^{*}$ & 0.06 \\
Fixed Effects & $(3.30)$ & $(0.77)$ & $(0.04)$ \\
Dummy Year & Yes & Yes & Yes \\
Dummy Country & Yes & Yes & Yes \\
Dummy Industry & Yes & Yes & Yes \\
Adjusted R & Yes & Yes & Yes \\
Number of firms & 0.03 & 0.16 & 0.03 \\
Number of observations & 585 & 586 & 586 \\
\hline
\end{tabular}

Source: authors' elaboration.

Note. Standard errors are in the parentheses. ${ }^{*} \mathrm{p}<0.10,{ }^{* *} \mathrm{p}<0.05,{ }^{* * *} \mathrm{p}<0.01$ (two-tailed test).

Table 17. CSR sustainability index

\begin{tabular}{llll}
\hline & ROE & ROA & TOBIN'S Q \\
\hline Constant & 110.94 & $123.99 * * *$ & 3.83 \\
R\&D INTENSITY & $(108.96)$ & $(37.52)$ & $(5.18)$ \\
& 38.83 & $-77.02^{* * *}$ & $-7.83^{* * *}$ \\
FIRM SIZE & $(68.36)$ & $(27.30)$ & $(2.21)$ \\
& -6.16 & $-6.88^{* * *}$ & -0.13 \\
LEVERAGE & $(6.38)$ & $(2.28)$ & $(0.31)$ \\
& 0.77 & 0.28 & 0.00 \\
EBITDA MARGIN & $(1.76)$ & $(0.34)$ & $(0.00)$ \\
& $0.02^{* * *}$ & $0.02^{* * *}$ & $-0.00^{* *}$ \\
CSR SUSTAINABILITY INDEX & $(0.00)$ & $(0.00)$ & $(0.00)$ \\
& -4.49 & -0.27 & 0.05 \\
Fixed Effects & $(3.84)$ & $(0.61)$ & $(0.04)$ \\
Dummy Year & Yes & Yes & Yes \\
Dummy Country & Yes & Yes & Yes \\
Dummy Industry & Yes & Yes & Yes \\
Adjusted R & Yes & Yes & Yes \\
Number of firms & 0.02 & 0.16 & 0.03 \\
Number of observations & 585 & 586 & 586 \\
\hline
\end{tabular}

Source: authors' elaboration.

Note. Standard errors are in the parentheses. ${ }^{*} \mathrm{p}<0.10,{ }^{* *} \mathrm{p}<0.05,{ }^{* * *} \mathrm{p}<0.01$ (two-tailed test). 
Table 18. CSR sustainability reporting

\begin{tabular}{llll}
\hline & ROE & ROA & TOBIN'S Q \\
\hline Constant & 107.54 & $124.23^{* * *}$ & 3.87 \\
& $(110.06)$ & $(37.44)$ & $(5.18)$ \\
R\&D INTENSITY & -39.49 & $-7741^{* * *}$ & $-7.82^{* * *}$ \\
& $(68.04)$ & $(27.41)$ & $(2.21)$ \\
FIRM SIZE & -5.98 & $-6.88^{* * *}$ & -0.14 \\
& $(6.44)$ & $(2.28)$ & $(0.31)$ \\
LEVERAGE & 0.76 & 0.28 & 0.00 \\
& $(1.76)$ & $(0.35)$ & $(0.00)$ \\
EBITDA MARGIN & $0.02^{* * *}$ & $0.02^{* * *}$ & $-0.00^{* *}$ \\
CSR SUSTAINABILITY & $(0.00)$ & $(0.00)$ & $(0.00)$ \\
REPORTING & -2.42 & $-1.37 *$ & 0.03 \\
Fixed Effects & $(2.50)$ & $(0.83)$ & $(0.04)$ \\
Dummy Years & Yes & Yes & Yes \\
Dummy Country & Yes & Yes & Yes \\
Dummy Industry & Yes & Yes & Yes \\
Adjusted R & Yes & Yes & Yes \\
Number of firms & 0.02 & 0.16 & 0.03 \\
Number of observations & 585 & 586 & 586 \\
\hline
\end{tabular}

Source: authors' elaboration.

Note. Standard errors are in the parentheses. ${ }^{*} \mathrm{p}<0.10,{ }^{* *} \mathrm{p}<0.05,{ }^{* * *} \mathrm{p}<0.01$ (two-tailed test).

Table 19. CSR responsibility awards

\begin{tabular}{llll}
\hline & ROE & ROA & TOBIN'S Q \\
\hline Constant & 106.77 & $123.81^{* * *}$ & 3.88 \\
R\&D INTENSITY & $(110.27)$ & $(-23.50)$ & $(5.18)$ \\
& -38.59 & $-76.90^{* * *}$ & $-7.84^{* * *}$ \\
FIRM SIZE & $(68.03)$ & $(27.27)$ & $(2.21)$ \\
& -5.96 & $-6.87 * * *$ & -0.14 \\
LEVERAGE & $(6.45)$ & $(2.29)$ & $(0.31)$ \\
& 0.77 & 0.28 & 0.00 \\
EBITDA MARGIN & $(1.76)$ & $(0.35)$ & $(0.00)$ \\
& $0.03 * * *$ & $-0.00^{* *}$ \\
CSR RESPONSIBILITY AWARDS & $(0.00)$ & $0.02 * * *$ & $(0.00)$ \\
& 0.51 & $(0.00)$ & -0.01 \\
Fixed Effects & $(1.66)$ & 0.27 & $(0.03)$ \\
Dummy Years & Yes & $(0.62)$ & Yes \\
Dummy Country & Yes & Yes & Yes \\
Dummy Industry & Yes & Yes & Yes \\
Adjusted R & Yes & Yes & Yes \\
Number of firms & 0.02 & Yes & 0.03 \\
Number of observations & 585 & 0.16 & 586 \\
\hline
\end{tabular}

Source: authors' elaboration.

Note. Standard errors are in the parentheses. ${ }^{*} \mathrm{p}<0.10,{ }^{* *} \mathrm{p}<0.05,{ }^{* * *} \mathrm{p}<0.01$ (two-tailed test). 
Table 20. Emissions Reduction

\begin{tabular}{llll}
\hline & ROE & ROA & TOBIN'S Q \\
\hline Constant & 105.83 & $123.21^{* * *}$ & 3.92 \\
R\&D INTENSITY & $(108.58)$ & $(36.95)$ & $(5.17)$ \\
& -38.36 & $-76.62^{* * *}$ & $-7.85^{* * *}$ \\
FIRM SIZE & $(67.81)$ & $(27.27)$ & $(2.20)$ \\
& -5.97 & $-6.89^{* * *}$ & -0.13 \\
LEVERAGE & $(6.50)$ & $(2.28)$ & $(0.31)$ \\
& 0.77 & 0.28 & 0.00 \\
EBITDA MARGIN & $(1.76)$ & $(0.34)$ & $(0.00)$ \\
& $0.03^{* * *}$ & $0.02^{* * *}$ & $-0.00^{* *}$ \\
EMISSIONS REDUCTION & $(0.00)$ & $(0.00)$ & $(0.00)$ \\
& 0.03 & 0.02 & -0.00 \\
Fixed Effects & $(0.08)$ & $(0.02)$ & $(0.00)$ \\
Dummy Years & Yes & Yes & Yes \\
Dummy Country & Yes & Yes & Yes \\
Dummy Industry & Yes & Yes & Yes \\
Adjusted R & Yes & Yes & Yes \\
Number of firms & 0.02 & 0.16 & 0.03 \\
Number of observations & 585 & 586 & 586 \\
\hline
\end{tabular}

Source: authors' elaboration.

Note. Standard errors are in the parentheses. ${ }^{*} \mathrm{p}<0.10,{ }^{* *} \mathrm{p}<0.05,{ }^{* * *} \mathrm{p}<0.01$ (two-tailed test).

Table 21. Resources reduction

\begin{tabular}{llll}
\hline & ROE & ROA & TOBIN'S Q \\
\hline Constant & 106.20 & $123.49^{* * *}$ & 3.86 \\
R\&D INTENSITY & $(110.64)$ & $(37.57)$ & $(5.15)$ \\
& -39.13 & $-77.19 * * *$ & $-7.85^{* * *}$ \\
FIRM SIZE & $(67.86)$ & $(27.26)$ & $(2.20)$ \\
& -5.81 & $-6.79^{* * *}$ & -0.13 \\
LEVERAGE & $(6.57)$ & $(2.29)$ & $(0.31)$ \\
& 0.77 & 0.28 & 0.00 \\
EBITDA MARGIN & $(1.76)$ & $(0.35)$ & $(0.00)$ \\
& $0.03 * *$ & $0.02 * * *$ & $-0.00^{* *}$ \\
RESOURCES REDUCTION & $(0.00)$ & $(0.00)$ & $(0.00)$ \\
& -0.03 & -0.02 & $-0.00^{*}$ \\
Fixed Effects & $(0.05)$ & $(0.01)$ & $(0.00)$ \\
Dummy Years & Yes & Yes & Yes \\
Dummy Country & Yes & Yes & Yes \\
Dummy Industry & Yes & Yes & Yes \\
Adjusted R & Yes & Yes & Yes \\
Number of firms & 0.02 & 0.16 & 0.03 \\
Number of observations & 585 & 586 & 586 \\
\hline
\end{tabular}

Source: authors' elaboration.

Note. Standard errors are in the parentheses. ${ }^{*} \mathrm{p}<0.10,{ }^{* *} \mathrm{p}<0.05,{ }^{* * *} \mathrm{p}<0.01$ (two-tailed test).

APPENDIX D: Impact of single Sustainability Score dimensions on financial performance: post-crisis subsample (2009-2013) 
Table 22. CSR sustainability committee

\begin{tabular}{|c|c|c|c|}
\hline & ROE & ROA & TOBIN'S Q \\
\hline Constant & $\begin{array}{l}35.34 \\
(37.06)\end{array}$ & $\begin{array}{l}42.86^{*} \\
(23.02)\end{array}$ & $\begin{array}{l}12.91 * * * \\
(2.40)\end{array}$ \\
\hline R\&D INTENSITY & $\begin{array}{l}43.31 * * * \\
(10.21)\end{array}$ & $\begin{array}{l}27.40 * * * \\
(6.91)\end{array}$ & $\begin{array}{l}0.45^{* *} \\
(0.21)\end{array}$ \\
\hline FIRM SIZE & $\begin{array}{l}-2.00 \\
(2.19)\end{array}$ & $\begin{array}{l}-2.33^{*} \\
(1.36)\end{array}$ & $\begin{array}{l}-0.69 * * * \\
(0.14)\end{array}$ \\
\hline LEVERAGE & $\begin{array}{l}-0.65 \\
(0.62)\end{array}$ & $\begin{array}{l}-0.66 \\
(0.45)\end{array}$ & $\begin{array}{l}-0.03 \\
(0.01)\end{array}$ \\
\hline EBITDA MARGIN & $\begin{array}{l}52.91 * * * \\
(8.40)\end{array}$ & $\begin{array}{l}35.30 * * * \\
(5.73)\end{array}$ & $\begin{array}{l}0.45^{* *} \\
(0.18)\end{array}$ \\
\hline $\begin{array}{l}\text { CSR SUSTAINABILITY } \\
\text { COMMITTEE }\end{array}$ & $\begin{array}{l}0.30 \\
(1.16)\end{array}$ & $\begin{array}{l}-0.20 \\
(0.68)\end{array}$ & $\begin{array}{l}0.01 \\
(0.04)\end{array}$ \\
\hline Fixed Effects & Yes & Yes & Yes \\
\hline Dummy Year & Yes & Yes & Yes \\
\hline Dummy Country & Yes & Yes & Yes \\
\hline Dummy Industry & Yes & Yes & Yes \\
\hline Adjusted R & 0.13 & 0.14 & 0.19 \\
\hline Number of firms & 589 & 590 & 590 \\
\hline Number of observations & 2,860 & 2,865 & 2,865 \\
\hline
\end{tabular}

Source: authors' elaboration.

Note. Standard errors are in the parentheses. ${ }^{*} \mathrm{p}<0.10, * * \mathrm{p}<0.05, * * * \mathrm{p}<0.01$ (two-tailed test).

Table 23. CSR sustainability index

\begin{tabular}{llll}
\hline & ROE & ROA & TOBIN'S Q \\
\hline Constant & 35.21 & $42.84^{*}$ & $12.95^{* * *}$ \\
R\&D INTENSITY & $(37.19)$ & $(23.01)$ & $(2.40)$ \\
& $43.33^{* * *}$ & $27.39^{* * *}$ & $0.46^{* *}$ \\
FIRM SIZE & $(10.21)$ & $(6.91)$ & $(0.21)$ \\
& -1.98 & $-2.34 *$ & $-0.69^{* * *}$ \\
LEVERAGE & $(2.18)$ & $(1.35)$ & $(0.13)$ \\
& -0.65 & -0.66 & -0.02 \\
EBITDA MARGIN & $(0.62)$ & $(0.45)$ & $(0.01)$ \\
& $52.92^{* * *}$ & $35.30^{* * *}$ & $0.46^{* *}$ \\
CSR SUSTAINABILITY INDEX & $(8.40)$ & $(5.73)$ & $(0.18)$ \\
& -0.20 & 0.01 & 0.05 \\
Fixed Effects & $(0.81)$ & $(0.52)$ & $(0.05)$ \\
Dummy Year & Yes & Yes & Yes \\
Dummy Country & Yes & Yes & Yes \\
Dummy Industry & Yes & Yes & Yes \\
Adjusted R & Yes & Yes & Yes \\
Number of firms & 0.13 & 0.14 & 0.19 \\
Number of observations & 589 & 590 & 590 \\
\hline
\end{tabular}

Source: authors' elaboration.

Note: Standard errors are in the parentheses. ${ }^{*} \mathrm{p}<0.10,{ }^{* *} \mathrm{p}<0.05,{ }^{* * *} \mathrm{p}<0.01$ (two-tailed test). 
Table 24. CSR sustainability reporting

\begin{tabular}{llll}
\hline & ROE & ROA & TOBIN'S Q \\
\hline Constant & 35.50 & $42.70^{*}$ & $12.92^{* * *}$ \\
& $(37.14)$ & $(23.09)$ & $(2.40)$ \\
R\&D INTENSITY & $43.30^{* * *}$ & $27.42^{* * *}$ & $0.45^{* *}$ \\
& $(10.22)$ & $(6.91)$ & $(0.21)$ \\
FIRM SIZE & -2.02 & $-2.32^{*}$ & $-0.69^{* * *}$ \\
& $(2.19)$ & $(1.36)$ & $(0.14)$ \\
LEVERAGE & -0.65 & 0.66 & -0.02 \\
& $(0.52)$ & $(0.45)$ & $(0.01)$ \\
EBITDA MARGIN & $52.90^{* * *}$ & $35.32 * * *$ & $0.45^{* *}$ \\
CSR SUSTAINABILITY & $(8.41)$ & $(5.74)$ & $(0.18)$ \\
REPORTING & 0.42 & -0.35 & 0.00 \\
Fixed Effects & $(0.45)$ & $(0.57)$ & $(0.04)$ \\
Dummy Years & Yes & Yes & Yes \\
Dummy Country & Yes & Yes & Yes \\
Dummy Industry & Yes & Yes & Yes \\
Adjusted R & Yes & Yes & Yes \\
Number of firms & 0.13 & 0.14 & 0.19 \\
Number of observations & 589 & 590 & 590 \\
\hline
\end{tabular}

Source: authors' elaboration.

Note. Standard errors are in the parentheses. ${ }^{*} \mathrm{p}<0.10,{ }^{* *} \mathrm{p}<0.05,{ }^{* * *} \mathrm{p}<0.01$ (two-tailed test).

Table 25. CSR responsibility awards

\begin{tabular}{llll}
\hline & ROE & ROA & TOBIN'S Q \\
\hline Constant & 35.75 & $43.06^{*}$ & $12.90^{* * *}$ \\
R\&D INTENSITY & $(37.03)$ & $(22.86)$ & $(2.40)$ \\
& $43.35^{* * *}$ & $27.39^{* * *}$ & $0.45^{* *}$ \\
FIRM SIZE & $(10.21)$ & $(6.90)$ & $(0.21)$ \\
& -2.02 & $-2.36^{*}$ & $-0.68^{* * *}$ \\
LEVERAGE & $(2.17)$ & $(1.35)$ & $(0.14)$ \\
& -0.65 & -0.66 & -0.02 \\
EBITDA MARGIN & $(0.52)$ & $(0.45)$ & $(0.01)$ \\
& $52.91^{* * *}$ & $35.27 * * *$ & $0.45^{* *}$ \\
CSR RESPONSIBILITY AWARDS & $(8.41)$ & $(5.73)$ & $(0.18)$ \\
& 0.14 & 0.20 & 0.02 \\
Fixed Effects & $(0.47)$ & $(0.33)$ & $(0.03)$ \\
Dummy Years & Yes & Yes & Yes \\
Dummy Country & Yes & Yes & Yes \\
Dummy Industry & Yes & Yes & Yes \\
Adjusted R & Yes & Yes & Yes \\
Number of firms & 0.13 & 0.14 & 0.19 \\
Number of observations & 589 & 590 & 590 \\
\hline
\end{tabular}

Source: authors' elaboration.

Note. Standard errors are in the parentheses. ${ }^{*} \mathrm{p}<0.10,{ }^{* *} \mathrm{p}<0.05,{ }^{* * *} \mathrm{p}<0.01$ (two-tailed test). 
Table 26. Emissions Reduction

\begin{tabular}{llll}
\hline & ROE & ROA & TOBIN'S Q \\
\hline Constant & 35.39 & $41.97^{*}$ & $12.90^{* * *}$ \\
R\&D INTENSITY & $(36.76)$ & $(22.60)$ & $(2.41)$ \\
& $43.33^{* * *}$ & $27.37^{* * *}$ & $0.45^{* *}$ \\
FIRM SIZE & $(10.22)$ & $(6.91)$ & $(0.21)$ \\
& -1.99 & $-2.34^{*}$ & $-0.69^{* * *}$ \\
LEVERAGE & $(2.17)$ & $(1.34)$ & $(0.14)$ \\
& -0.65 & -0.66 & 0.02 \\
EBITDA MARGIN & $(0.52)$ & $(0.45)$ & $(0.01)$ \\
& $52.92^{* * *}$ & $35.28^{* * *}$ & $0.45^{* *}$ \\
EMISSIONS REDUCTION & $(8.40)$ & $(5.74)$ & $(0.18)$ \\
& -0.00 & 0.01 & 0.00 \\
Fixed Effects & $(0.02)$ & $(0.01)$ & $(0.00)$ \\
Dummy Years & Yes & Yes & Yes \\
Dummy Country & Yes & Yes & Yes \\
Dummy Industry & Yes & Yes & Yes \\
Adjusted R & Yes & Yes & Yes \\
Number of firms & 0.13 & 0.14 & 0.19 \\
Number of observations & 589 & 590 & 590 \\
\hline
\end{tabular}

Source: authors' elaboration.

Note. Standard errors are in the parentheses. ${ }^{*} \mathrm{p}<0.10,{ }^{* *} \mathrm{p}<0.05,{ }^{* * *} \mathrm{p}<0.01$ (two-tailed test).

Table 27. Resources reduction

\begin{tabular}{llll}
\hline & ROE & ROA & TOBIN'S Q \\
Constant & 35.37 & $42.84^{*}$ & $12.91^{* * *}$ \\
R\&D INTENSITY & $(36.7)$ & $(22.80)$ & $(2.40)$ \\
& $43.36^{* * *}$ & $27.41^{* * *}$ & $0.45^{* *}$ \\
FIRM SIZE & $(10.21)$ & $(6.91)$ & $(0.21)$ \\
& -2.08 & $-2.39^{*}$ & $-0.69^{* * *}$ \\
LEVERAGE & $(2.18)$ & $(1.36)$ & $(0.14)$ \\
& -0.65 & -0.66 & -0.02 \\
EBITDA MARGIN & $(0.52)$ & $(0.45)$ & $(0.01)$ \\
& $52.95^{* * *}$ & $35.31^{* * *}$ & $0.45^{* *}$ \\
RESOURCES REDUCTION & $(8.40)$ & $(5.74)$ & $(0.18)$ \\
& 0.02 & 0.01 & 0.00 \\
Fixed Effects & $(0.02)$ & $(0.01)$ & $(0.00)$ \\
Dummy Years & Yes & Yes & Yes \\
Dummy Country & Yes & Yes & Yes \\
Dummy Industry & Yes & Yes & Yes \\
Adjusted R & Yes & Yes & Yes \\
Number of firms & 0.13 & 0.14 & 0.19 \\
Number of observations & 589 & 590 & 590 \\
\hline
\end{tabular}

Source: authors' elaboration.

Note. Standard errors are in the parentheses. ${ }^{*} \mathrm{p}<0.10,{ }^{* *} \mathrm{p}<0.05, * * * \mathrm{p}<0.01$ (two-tailed test).

APPENDIX E: Holistic approach hypotheses

Hypothesis 4a: The existence of a CSR sustainability committee enhances the firm's operating performance (ROA), all else equal.

Hypothesis $4 \mathrm{~b}$ : The existence of a CSR sustainability committee enhances the firm's financial market performance (Tobin's Q), all else equal.

Hypothesis 4c: The existence of a CSR sustainability committee enhances the firm's financial performance (ROE), 
all else equal.

Hypothesis 5a: Belonging to a specific sustainability index enhances the firm's operating performance (ROA), all else equal.

Hypothesis 5b: Belonging to a specific sustainability index enhances the firm's financial market performance (Tobin's Q), all else equal.

Hypothesis 5c: Belonging to a specific sustainability index enhances the firm's financial performance (ROE), all else equal.

Hypothesis 6a: Having a separate sustainability report published or a section in the firm's annual report focused on sustainability enhances the firm's operating performance (ROA), all else equal.

Hypothesis 6b: Having a separate sustainability report published or a section in the firm's annual report focused on sustainability enhances the firm's financial market performance (Tobin's Q), all else equal.

Hypothesis 6c: Having a separate sustainability report published or a section in the firm's annual report focused on sustainability enhances the firm's financial performance (ROE), all else equal.

Hypothesis 7a: Having received one or more awards for the firm's social, ethical, community, or environmental activities and performance enhances the firm's operating performance (ROA), all else equal.

Hypothesis 7b: Having received one or more awards for the firm's social, ethical, community, or environmental activities and performance enhances the firm's financial market performance (Tobin's Q), all else equal.

Hypothesis 7c: Having received one or more awards for the firm's social, ethical, community, or environmental activities and performance enhances the firm's financial performance (ROE), all else equal.

Hypothesis 8a: An emissions reduction value bigger than the sample's emissions reduction median enhances the firm's operating performance (ROA), all else equal.

Hypothesis 8b: An emissions reduction value bigger than the sample's emissions reduction median enhances the firm's financial market performance (Tobin's Q), all else equal.

Hypothesis 8c: An emissions reduction value bigger than the sample's emissions reduction median enhances the firm's financial performance (ROE), all else equal.

Hypothesis 9a: A resources reduction value bigger than the sample's emissions reduction median enhances the firm's operating performance (ROA), all else equal.

Hypothesis 9b: A resources reduction value bigger than the sample's emissions reduction median in enhances the firm's financial market performance (Tobin's Q), all else equal.

Hypothesis 9c: A resources reduction value bigger than the sample's emissions reduction median enhances the firm's financial performance (ROE), all else equal.

\section{Copyrights}

Copyright for this article is retained by the author(s), with first publication rights granted to the journal.

This is an open-access article distributed under the terms and conditions of the Creative Commons Attribution license (http://creativecommons.org/licenses/by/4.0/). 